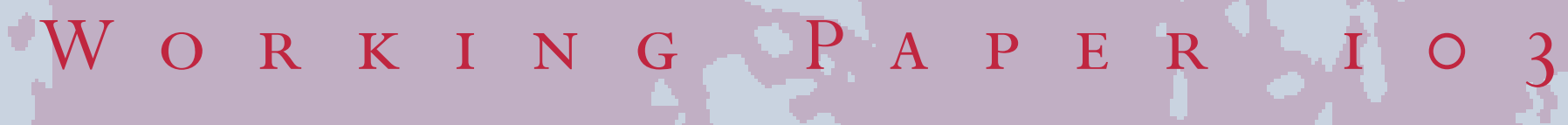
DOES MONEY MATTER FOR INFLATION

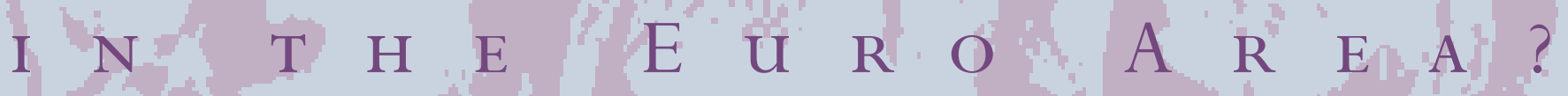




\section{Editorial Board of the Working Papers}

Eduard Hochreiter, Coordinating Editor

Ernest Gnan,

Guenther Thonabauer

Peter Mooslechner

Doris Ritzberger-Gruenwald

\section{Statement of Purpose}

The Working Paper series of the Oesterreichische Nationalbank is designed to disseminate and to provide a platform for discussion of either work of the staff of the OeNB economists or outside contributors on topics which are of special interest to the OeNB. To ensure the high quality of their content, the contributions are subjected to an international refereeing process. The opinions are strictly those of the authors and do in no way commit the OeNB.

Imprint: Responsibility according to Austrian media law: Guenther Thonabauer, Secretariat of the Board of Executive Directors, Oesterreichische Nationalbank

Published and printed by Oesterreichische Nationalbank, Wien.

The Working Papers are also available on our website:

http://www.oenb.at 


\section{Editorial}

In this paper the authors analyse the role of M3 as an indicator for future inflation and correspondingly for current monetary policy in the euro area. Short and long run interrelationship between inflation and money growth are analysed in an error correction framework taking into account the output gap and short and long term interest rates. A robust cointegration is found between money growth and inflation. In the long run, shocks in M3-growth account for 33 percent to 40 percent of the inflation forecast error variance. The effects of output gap and interest rate shocks on inflation are mainly transitory and there forecasting variance shares are negligible for medium term horizons. There is evidence for a second regime prevailing at the end of the seventies and beginning of the eighties which relates to periods of high interest rate and inflation rate levels and decreasing rates in real money growth. Overall, the authors present firm evidence for a stable dynamic relationship between money growth and inflation which implies that the deviation of the real money growth from its long run average is a good indicator of future inflation acceleration or deceleration. Of course, this finding provides evidence in favour of the recently de-emphasised first pillar of the ECB strategy. According to the results, however, an M3-growth rate of slightly above 5\% is compatible with a nonaccelerating average rate of inflation of $2 \%$.

September 19, 2005 



\title{
Does Money Matter for Inflation in the Euro Area?
}

\author{
Peter Kugler \\ WWZ/University of Basel and \\ Swiss National Bank \\ Sylvia Kaufmann ${ }^{1}$ \\ Oesterreichische Nationalbank
}

\begin{abstract}
This paper analyses the role of M3 as an indicator for future inflation and correspondingly for current monetary policy in the euro area. We analyse the short and long run interrelationship between inflation and money growth in an error correction framework taking into account the output gap and short and long term interest rates. We find robust cointegration between money growth and inflation. In the long run, shocks in M3-growth account for 33 percent to 40 percent of the inflation forecast error variance. The effects of output gap and interest rate shocks on inflation are mainly transitory and there forecasting variance shares are negligible for medium term horizons. There is evidence for a second regime prevailing at the end of the seventies and beginning of the eighties which relates to periods of high interest rate and inflation rate levels and decreasing rates in real money growth. Overall, we present firm evidence for a stable dynamic relationship between money growth and inflation which implies that the deviation of the real money growth from its long run average is a good indicator of future inflation acceleration or deceleration. Of course, this finding provides evidence in favour of the recently de-emphasised first pillar of the ECB strategy. According to our results, however, an M3-growth rate of slightly above 5\% is compatible with a non-accelerating average rate of inflation of $2 \%$.
\end{abstract}

First Draft January 2005

Last Revision September 2005

\footnotetext{
${ }^{1}$ The views presented in the paper are those of the authors and do not necessarily represent the views of the OeNB or the SNB. The first draft of the paper was presented in a seminar at the OeNB, the International Atlantic Economic Society Conference, London, March 2005 and the Annual Conference of the Western Economic Association, San Francisco, July 2005. Helpful comments of participants of this seminar and these conferences and of an anonymous referee are gratefully acknowledged.
} 


\section{Introduction}

There is mixed recent empirical evidence concerning the role of the money stock M3 as an indicator for future inflation and correspondingly current monetary policy. On the one hand, the data since 2001 raise a substantial doubt about the existence of a stable long run money demand function, which seemed to be firmly established with data of the 1980s and 1990s (see for instance Bruggeman, Donati and Warne, 2003, Carstensen, 2003). Moreover, there are some studies concluding that the predictive power of money growth for inflation is only minor, and higher for other variables like the output gap or the real money gap (Gerlach and Svensson, 2003; Nicolletti Altimari, 2001). On the other hand, this negative evidence for the relevance of M3 in the euro area is questioned by recent papers concentrating on the relationship between trend inflation and money growth, both either approximated by HPfiltered values (Neumann, 2003; Neumann and Greiber, 2004, von Hagen, 2004) or by exponentially weighted moving averages (Gerlach, 2004).

This paper provides additional empirical evidence for the relevance of money growth for inflation in the euro area. Instead of relying on constructed variables, such as core money growth, trend inflation or real money and price gaps, and designing a specific structural model of inflation dynamics based on the assumption of a stable long run money demand (as for instance Neumann, 2003; Gerlach and Svensson, 2003 and von Hagen, 2004), we analyse the short and long run relationship between inflation and money growth in an error correction framework, also including the output gap (or GDP growth) and short and long term interest rates. This procedure is motivated by unit root and cointegration tests, which indicate that the order of integration differs between the variables included in the analysis: prices and money appear to be $\mathrm{I}(2)$ and cointegrated in their growth rates, the short term and the long term interest rate are indicated to be I(1) and cointegrated, and the output gap enters the analysis, of course, as a stationary series.

Coenen and Vega (1999) and more recently Holtemöller (2004), with data up to 2001, also make a case for second order integrated money and prices. The extension of the sample to 2003 destroys the stable long run money demand function found by these authors, as also found in Gerlach and Svensson (2003) and von Hagen (2004). With the analysis of quarterly series which date back to the mid-seventies, we instead find a strong cointegrating relationship between euro area inflation and money growth with error correction in both variables. Moreover, the impulse response analysis and the variance decomposition yield 
evidence for a highly significant effect of shocks in M3 growth on inflation, accounting in the long run for approximately 40 percent of the inflation's forecast error variance. On the other hand, effects of shocks in the output gap and in both interest rates on inflation are only transitory and vanish in the medium term.

Finally, the estimation of a Markov switching variant of our error correction vector autoregression (EC-VAR) model yields the identification of a second regime which was relevant at the end of the seventies and beginning of the eighties, reflecting the change in US monetary policy leading to very volatile interest rates which were transmitted internationally in a period of rising inflation rates and decreasing money growth rates. However, the "normal" regime, which prevails otherwise most of the time, displays similar long-run and transitional patterns as the linear model, in particular during the recent past. In sum, we present firm evidence for a reasonably stable dynamic relationship between money growth and inflation supporting the "old" first pillar of the ECB monetary policy strategies which was recently de-emphasised. According to our results, however, an M3-growth rate of slightly above $5 \%$ is compatible with a non-accelerating average rate of inflation of $2 \%$.

The content of this paper is organized as follows: section 2 contains the results of unit root and stationarity tests which form the basis for the specification of the EC-VAR used afterwards. The result of the EC-VAR analysis is presented in section 3 . The findings of the Markov switching EC-VAR are discussed in section 4. Section 5 concludes.

\section{Unit Root and Stationarity Tests}

In this section we present the results of unit root and stationarity tests for six quarterly euro area time series, namely inflation measured by the harmonized CPI $(\Delta \mathrm{p})$, GDP growth $(\Delta y)$, the output gap (x, defined as the log of the ratio of output to potential output), M3 growth $(\Delta \mathrm{m})$, the long term nominal interest rate $(10$ years government bond rate, $\mathrm{R}$ ) and the short term interest rate (3 months rate, $\mathrm{r}$ ) using data from the midseventies to $2003^{2}$. All level variables are defined in natural logarithms except the two interest rates. This data set covers more or less the post Bretton Woods flexible exchange rate period. The data of the seventies are included as they provide a lot of variation in money growth and inflation which should not be neglected in the analysis. However, the results do not essentially

\footnotetext{
${ }^{2}$ The data are from the area wide model data base provided by the ECB except M3 which was kindly provided by Boris Hofmann. All series are seasonally adjusted except for the interest rates.
} 
change when we restrict the sample period to begin in 1980, the estimates are only a bit less precise.

Table 1 contains the results of the Augmented Dickey-Fuller (ADF) unit root tests and the Kwiatkowski-Phillips-Schmidt-Shin (KPSS) stationarity tests for the time series and, if appropriate, for their first differences. Moreover, we consider a couple of linear combinations, namely real money (m-p), velocity (m-p-y), the term spread (R-r) and the real interest rates (r$\Delta \mathrm{p}, \mathrm{R}-\Delta \mathrm{p})$. For the level series except for the interest rates a deterministic trend is included. For the ADF tests the lag length is selected according to the Schwarz information criterion, but the results are robust with respect to this choice. The autocorrelation correction for the variance estimate in the KPSS test is done according to the Newey-West procedure using the Bartlett window with sample size dependent width. The results are robust with respect to reasonable variations in the window size.

We obtain very clear cut results for all variables except for the real interest rates in the sense that both the unit root test and the stationarity test lead to the same result. The price level and M3 appear to be I(2), and inflation and money growth are, therefore, I(1) but cointegrated, as real money is indicated to be I(1). Interest rates clearly appear to be I(1) but are cointegrated, which yields a stationary term spread. The tests point to an I(1) process for GDP and velocity against the alternative of a trend stationary series and the output gap is, as expected, stationary. The results are mixed, however, for the real interest rates, as we cannot reject both hypotheses for the short as well as the long rate.

In sum, our results suggest that we have six I(1) variables $(\Delta \mathrm{m}, \Delta \mathrm{p}, \mathrm{m}-\mathrm{p}, \mathrm{y}, \mathrm{r}, \mathrm{R})$ with two cointegrating relationships $(\Delta \mathrm{m}-\Delta \mathrm{p}, \mathrm{R}-\mathrm{r})$. In order to check whether there is a third cointegrating relationship representing a long run money demand function, we carried out some multivariate cointegration tests using Johansen's approach. To this end, we considered first a trivariate system (m-p, y, R), where the short term interest rate is excluded, because of the cointegration between the short and the long rate (see table 1). The trace test clearly points to no cointegration in this trivariate system: the corresponding trace test statistics are 33.62 (with deterministic trend in the cointegrating relationship) ${ }^{3}$ and 25.98 (without deterministic trend), which are lower than the 5 percent critical values of 42.44 and 29.68 , respectively.

\footnotetext{
${ }^{3}$ The test statistic is calculated using the small sample correction replacing the sample size T by T-kp (p is the number of variables and $k$ is the lag length) suggested by Reinsel and Ahn (1992) in the expression for the LR statistic.
} 
These test results are confirmed when the short rate is included. The trace statistics for the hypothesis of no cointegration in this four variable system with and without deterministic trend are 69.32 (5 percent value is 62.99) and 49.60 (5 percent value is 47.21), respectively. However, the hypothesis of at most one cointegrating relation cannot be rejected in both cases, even at the 10 percent level. Given the stationarity result found for the term spread in table 1 , these results clearly are at odds with an additional cointegrating relation representing a long run money demand function in the four variable system.

The cointegration analysis reported above is based on the assumption that, given the unit price elasticity of money demand we can reduce the system to an I(1) model. If this were not warranted, we would have to use the so-called multicointegration methodology allowing for $\mathrm{I}(2)$ and I(1) variables in a cointegrating relationship. The application of the extension of the Engle-Granger test suggested by Haldrup (1994) and Engsted, Gonzalo and Haldrup (1997) clearly points against a stable long run money demand: The corresponding Engle-Granger tstatistic for the null of no cointegration with log price level, log GDP and the long term interest rate as right hand side variables is -1.85 (without trend, $5 \%$ critical value -4.25 ) and 2.25 (with trend, 5\% critical value -4.58 ), respectively ${ }^{4}$.

This finding is usually attributed to permanent changes in money demand caused by structural changes arising in the European unification process during the last two decades and by increased uncertainty and/or low interest rates in the last three years. The latter problem can be accounted for by including (non stationary) measures of uncertainty in the cointegrating relationship (e.g. Carstensen, 2003) or using a nonlinear specification for the money demand function. However, we will not consider this issue here and proceed with two cointegrating relationships. This means that the money demand function produces (after taking first differences) a cointegrating relation between money growth and inflation with cointegrating vector $(1,-1)$, and that income, interest rates and velocity changes will have only a transitory effects on money growth and inflation.

\footnotetext{
${ }^{4}$ This finding is robust with respect to the specification of the cointegrating relationship (inclusion of inflation rate and/or short rate). However, shortening the sample to 2001 leads to a considerably larger t-statistics in absolute value. This result is in line with that of Holtemöller (2004) who found evidence in favour of a long run money demand function using Johansen's I(2) approach and data from $1984-2001$.
} 
Table 1: Results of Unit Roots and Stationarity Tests, 1975-2003

\begin{tabular}{|l|l|l|}
\hline Series & ADF & KPSS \\
\hline$\Delta \mathrm{m}$ & -2.46 & $0.998^{* *}$ \\
\hline$\Delta(\Delta \mathrm{m})$ & $-15.67 * * *$ & 0.141 \\
\hline$\Delta \mathrm{p}$ & -1.90 & $0.992^{* *}$ \\
\hline$\Delta(\Delta \mathrm{p})$ & $-7.00^{* * *}$ & 0.130 \\
\hline $\mathrm{r}$ & -1.32 & $0.795^{* *}$ \\
\hline$\Delta \mathrm{r}$ & $-6.88^{* * *}$ & 0.118 \\
\hline $\mathrm{R}$ & -1.06 & $0.799 * *$ \\
\hline$\Delta \mathrm{R}$ & $-6.16^{* * *}$ & 0.171 \\
\hline $\mathrm{x}$ & $-2.94 *$ & 0.095 \\
\hline$\Delta \mathrm{y}$ & $-8.47 * * *$ & 0.124 \\
\hline $\mathrm{m}-\mathrm{p}($ test with trend $)$ & -1.22 & $0.146 *$ \\
\hline$\Delta(\mathrm{m}-\mathrm{p})$ & $-6.98^{* * *}$ & 0.135 \\
\hline $\mathrm{m}-\mathrm{p}-\mathrm{y}$ (test with trend $)$ & -1.17 & $0.219 * *$ \\
\hline $\mathrm{r}-\Delta \mathrm{p}$ & -2.73 & 0.310 \\
\hline $\mathrm{R}-\Delta \mathrm{p}$ & -2.86 & 0.351 \\
\hline $\mathrm{R}-\mathrm{r}$ & $-4.03^{* *}$ & 0.317 \\
\hline
\end{tabular}

$*, * *$ and $* * *$ indicates statistical significance at the $5 \%, 1 \%$ and $0.1 \%$ level

\section{An EC-VAR Analysis of the Inflation-Money Growth Dynamics}

In order to analyze the dynamic interrelationship between money growth and inflation we include five variables, a short term and a long term interest rate, money growth, the output gap and inflation. According to the results of the unit root and the cointegration tests reported above we consider an error correction model for $\Delta \mathrm{r}, \Delta \mathrm{R}, \Delta(\Delta \mathrm{m}), \Delta \mathrm{x}$ and $\Delta(\Delta \mathrm{p})$ with three cointegrating relations R-r, $\Delta \mathrm{m}-\Delta \mathrm{p}$ and $\mathrm{x}$. For computational convenience in the impulse response and variance decomposition analysis, the stationary output gap (x) enters the ECVAR model in first differences, which has to be corrected by a third "degenerate" cointegration relationship $\mathrm{x}$.

The lag length in the level-VAR was selected as 4, which implies 3 lagged difference terms in the EC model. This choice is optimal according to the Final Prediction Error criterion. The Hannan-Quinn and Schwarz criteria suggest a lag length of 1, which leads clearly to autocorrelation in the model's residuals. On the other extreme, the Akaike criterion (AIC), 
which has a bimodal shape, shows a slightly lower value at lag 8 than at lag 4 . However, lag 8 seems to take up some extreme observations at the beginning of the sample and AIC leads to an optimal lag length of 4 when we use the sample from 1980 to 2003 . The estimation of the model is performed in a Bayesian setup, using Markov chain Monte Carlo simulation methods to obtain the posterior inference on the model parameters. We use conjugate prior distributions for all model parameters. They are non-informative for the constant, the error correction parameters and the covariance matrix of the residuals. For the parameters on lagged variables, we implement a Minnesota type prior with overall tightness 0.3 and weight for off-diagonal elements equal to 0.5 (Litterman, 1986, and Hamilton, 1994, pp. 360-362). The details on the Gibbs sampler used to obtain draws from the posterior distributions are found in Kaufmann and Valderrama (2004). ${ }^{5}$ Before turning to the empirical results, it is worthwhile to mention that we get essentially the same pattern of results when the output gap is replaced by the GDP growth rate.

The error correction coefficient estimates are reported in table 2. We clearly see statistically and economically significant reactions with EC coefficients of $-0.22,0.18$ and 0.31 on money growth acceleration, inflation acceleration and the output gap change, respectively, to lagged real money growth. Accordingly, real money growth is adjusted to its long run value by changes in nominal money growth and inflation acceleration of similar absolute sizes. Of course, this means that money is not weakly exogenous in our EC-VAR. This finding reflects a symmetric lagged partial adjustment of nominal money growth and inflation to changes in real money growth, which can be interpreted in two ways.The lagged adjustment of inflation to changes in real money growth may be caused by short run price rigidities, whereas the negative lagged adjustment of nominal money growth could be the result of a reaction of monetary policy, which is tightened (loosened) when real money growth was unusually high (low) in the past. On the other hand, under rational expectations, expectation effects may render current inflation dependent on expected future money growth. Therefore, we may get a "wrong" dynamic picture that money growth lags inflation although causality runs the opposite way ${ }^{6}$. Note that, in addition, lagged real money growth has a strongly positive

\footnotetext{
${ }^{5}$ Specifically, the lagged error correction terms enter the system as given variables. At each iteration of the sampler, the simulated VAR parameters are retained if they define a system which is stable (non-explosive) in the long-run, i.e. a system in the level variables (taking into account the cointegrating relationships) which has eigenvalues not greater than one.

${ }^{6}$ Consider the model with flexible prices and assume that the money demand is given by

$m_{t}-p_{t}=d_{t}+a y_{t}-b\left(E_{t} p_{t+1}-p_{t}\right)$

where $d$ is an exogenous variable reflecting the influence of real interest rates as well as other shifts and shocks in money demand and $E$ sub $t$ means conditional expectations given information at time $t$. Forward iteration of
} 
influence on the change in the output gap which in turn affects changes in inflation through lagged differences in the EC-VAR. How important all these effects are for the variability of inflation and money growth, can only be analysed in a variance decomposition exercise. As we will be see below in Figure 2, such an analysis shows that money growth shocks are very important for long run inflation variability whereas the opposite is not true.

The size of the reaction of the variables to the term spread is weaker and less statistically significant. However, we clearly can reject the joint hypothesis that the EC coefficients in the interest rates and the output gap equations are zero. Finally, note that according to the adjusted R-squared measures, the fit of the EC model is remarkable for a differenced model, in particular for the inflation rate acceleration where nearly half of the variation is explained by the model.

In order to prevent economically unreasonable effects like a permanent effect of the stationary output gap on interest rates, inflation and money growth, all EC coefficients on the lagged $\mathrm{x}$ are set to zero except in the equation for $\Delta \mathrm{x}$. In addition, the statistically insignificant term spread is excluded from the money growth acceleration and the inflation acceleration equations. These restrictions concerning the error correction structure are jointly tested with the restrictions on the cointegrating space, i.e. a stationary term spread, real money growth and a stationary output gap. The LR test statistic of this restricted model against the unrestricted I(1) VAR, which is asymptotically chi-squared distributed with 13 degrees of freedom under the null hypothesis, is $16.95^{7}$. Therefore, these restrictions cannot be rejected at usual significance levels (10 percent critical value is 19.81).

this equation under the assumption of exogenous money supply and rational expectations provides the following solution for the price level

$p_{t}=\frac{1}{1+b} \sum_{i=0}^{\infty}\left(\frac{b}{1+b}\right)^{i} E_{t}\left(d_{t+i}+m_{t+i}-a y_{t+i}\right)$.

Therefore, inflation leads money growth although prices are fully flexible and adjust instantaneously to changes in the money stock.

${ }^{7}$ The test statistic is calculated using the same small sample correction replacing T by T-pk as in the cointegration tests. 
Table 2: Error correction coefficients estimates and adj. R-squared in an EC-VAR(3) for the short rate, long rate, money growth, output gap and inflation in the euro area, 1975-2003

\begin{tabular}{|l|c|c|c|c|c|}
\hline & $\Delta \mathrm{r}$ & $\Delta \mathrm{R}$ & $\Delta(\Delta \mathrm{m})$ & $\Delta \mathrm{x}$ & $\Delta(\Delta \mathrm{p})$ \\
\hline & & & & & \\
\hline $\mathrm{R}-\mathrm{r}$ & 0.11 & -0.09 & 0.04 & 0.10 & 0.04 \\
\hline & $(0.07)$ & $(0.05)$ & $(0.05)$ & $(0.06)$ & $(0.04)$ \\
\hline$\Delta \mathrm{m}-\Delta \mathrm{p}$ & 0.02 & -0.02 & -0.22 & 0.32 & 0.18 \\
\hline & $(0.01)$ & $(0.08)$ & $(0.09)$ & $(0.10)$ & $(0.07)$ \\
\hline & & & & & \\
\hline $\mathrm{x}$ & 0.16 & 0.04 & 0.09 & -0.18 & 0.04 \\
\hline & $(0.07)$ & $(0.05)$ & $(0.05)$ & $(0.06)$ & $(0.04)$ \\
\hline & & & & & \\
\hline Adj. R-sq & 0.32 & 0.28 & 0.25 & 0.18 & 0.46 \\
\hline
\end{tabular}

Equations are in columns and cointegrating linear combinations in rows. Standard errors are given in parentheses.

The error correction coefficients give some important insights on the adjustment process. However, this is only part of the story in the sense that there are indirect channels operating through the lagged endogenous variables. For instance, lagged real money growth has strong effects on the change in the output gap which in turn may influence the change in the inflation rate with a lag. This indirect influence can be seen in the impulse response function which show the dynamic effect of a shock in one variable on all variables of the system. To this end, we orthogonalize the residuals using a Cholesky decomposition of the residuals' covariance matrix, given the ordering of the variables as in table 2 . Instead of using a structural VAR approach, we select this procedure because we are mainly interested in the effects of shocks in M3 growth in general, rather than in the effects of identified monetary policy or money demand shocks. Therefore, the reader should be aware that it does not make sense to give a structural interpretation to the impulse responses reported below. In particular, the shock in the short rate cannot be interpreted as a monetary policy shock, rather, it seems to be dominated by changes in inflation expectations. Of course, our approach may suffer from the arbitrary ordering of the variables. In our context, however, this is not a major problem as the residuals of the money growth equation are only weakly correlated with the four other residuals series. In fact we get essentially the same results for the impulse responses to money growth shocks for all other orderings. The impulse responses for 24 quarters and the corresponding forecast error variance decompositions are displayed in figure 1 and 2 , respectively. 
Figure 1: Accumulated impulse responses along with the $95 \%$ confidence interval, ECVAR(3), 1975-2003.

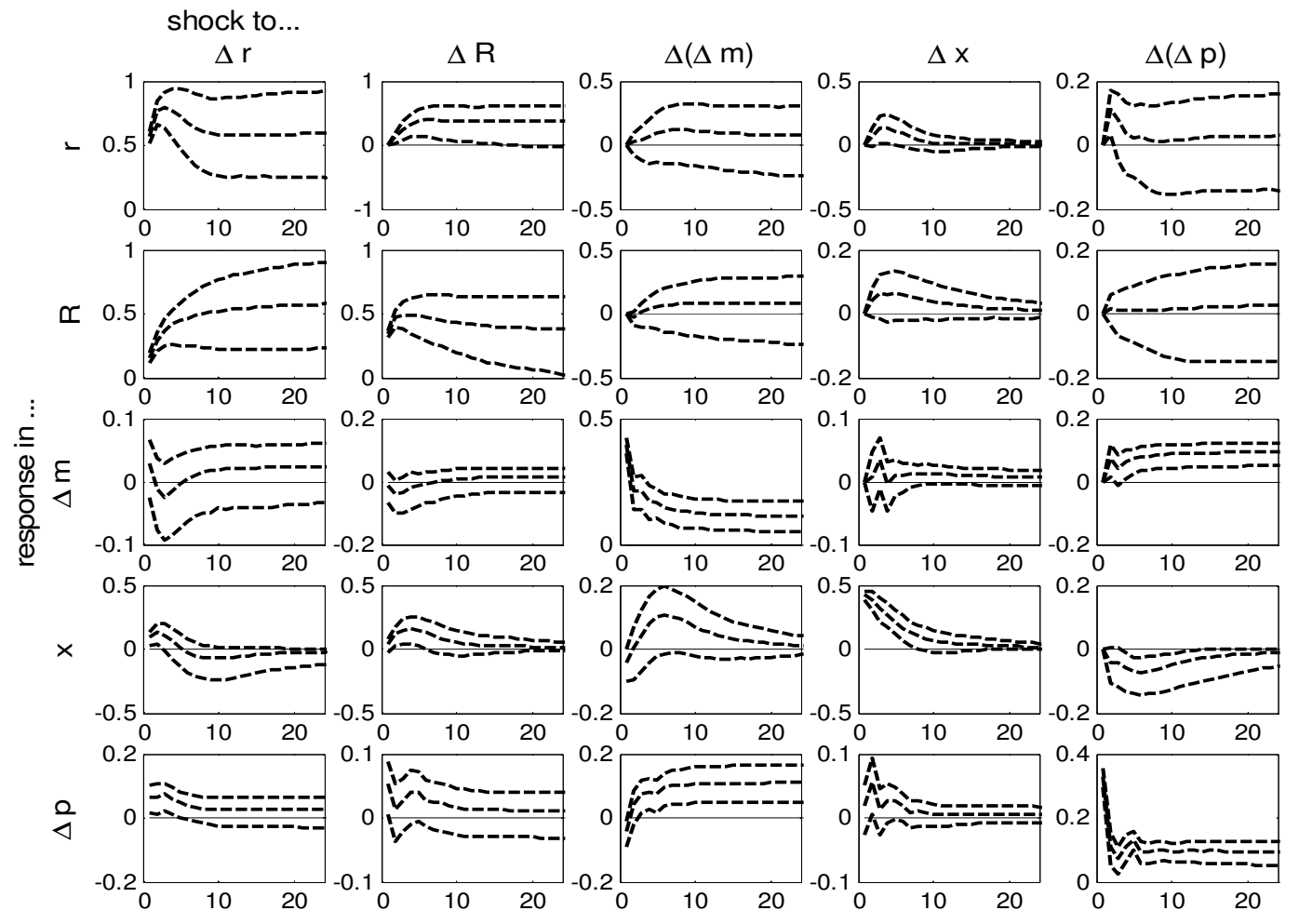

Now let us discuss some results of the impulse response and variance decomposition analysis, concentrating on the dynamic relationship between money growth and inflation. Figure 1 shows that a permanent shock in money growth (third column) leads to a transitory and insignificant increase in the short rate (first row) and in the long rate (second row) after a minor negative reaction at the beginning in the latter case. There is a long lasting but transitory significant positive effect on the output gap (fourth row) and a permanent effect on the inflation rate (fifth row). Shocks in the short term interest rate (first column) have a transitory positive effect on the output gap and on the inflation rate. In the first case, the effect is reversed after two years, and becomes insignificant in the second case. Shocks in the long term interest rate and the output gap have mostly transitory influences on inflation and decrease finally to zero in the long run.

This pattern of results is reflected by the forecast error variance decomposition displayed in figure 2: For short horizons up to four quarters, inflation variability is dominated by shocks (in decreasing order of magnitude) in the short rate, the output gap, the long rate and money growth. In the medium to long run (at a horizon longer than 15 quarters), however, money growth shocks account for at least 30 percent of inflation variability and only own inflation 
shocks are of greater importance. If we increase the horizon of the variance decomposition to 40 or 50 quarters, we end up with approximately the same share of variance explained by own shocks and money growth shocks, and with only negligible contributions of interest rates and output gap shocks. Finally, note that money exhibits a high degree of exogeneity in the sense that its forecast error variability is dominated by own shocks (over 80 percent up to 16 quarters and remaining over 70 percent at further increasing horizon) .

\section{Figure 2: Variance decomposition, EC-VAR(3), 1975-2003, mean estimate with $95 \%$ confidence interval}

forecast variance attributable to...

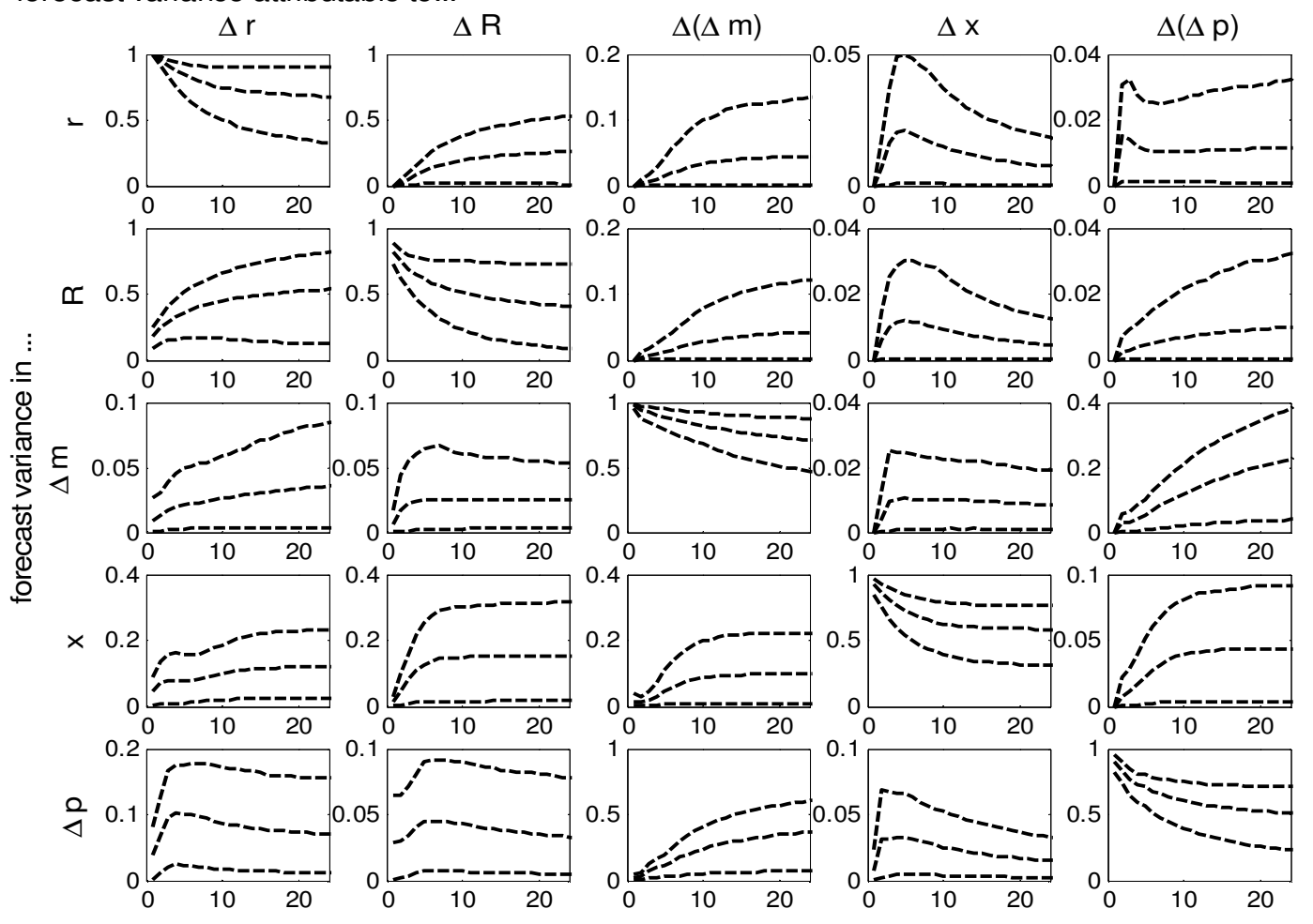

All the findings reported above suggest considering shocks to nominal M3 growth as leading indicators for inflation. Of course such an indicator of inflation is unusual and a directly observable variable is preferable. Fortunately, the one period lagged real money (M3) growth rate is not only conditionally but even unconditionally correlated with inflation acceleration. This can nicely be seen from the scatter plot displayed in figure 3 and from the fact that we calculate a simple correlation coefficient of 0.46 for these two variables, which is rather high given the very volatile quarterly inflation and money growth data. Of course, this indicator differs from the ECB reference value for nominal M3 growth in two respects: First, it is real money and not nominal money growth which is relevant. Even in times of relatively low and stable inflation this may make a difference as these two measures are strongly but not 
perfectly correlated (the correlation coefficient is 0.86 for 1999-2003). Second, and more importantly, real money growth is an important indicator for the change in future inflation. Thus, a real money growth at its long run level (3.2 percent per annum for the period 19752003) would be consistent with a constant inflation rate at its current level, whereas a value of real money growth below (above) this value would indicate disinflation (acceleration of inflation). This implies that an annual growth rate of nominal money of slightly above 5 percent would be appropriate to keep inflation at a current value around 2 percent according to our model.

Figure 3: Scatter Plot of Inflation Acceleration against Lagged Real Money Growth, Quarterly data 1975-2004

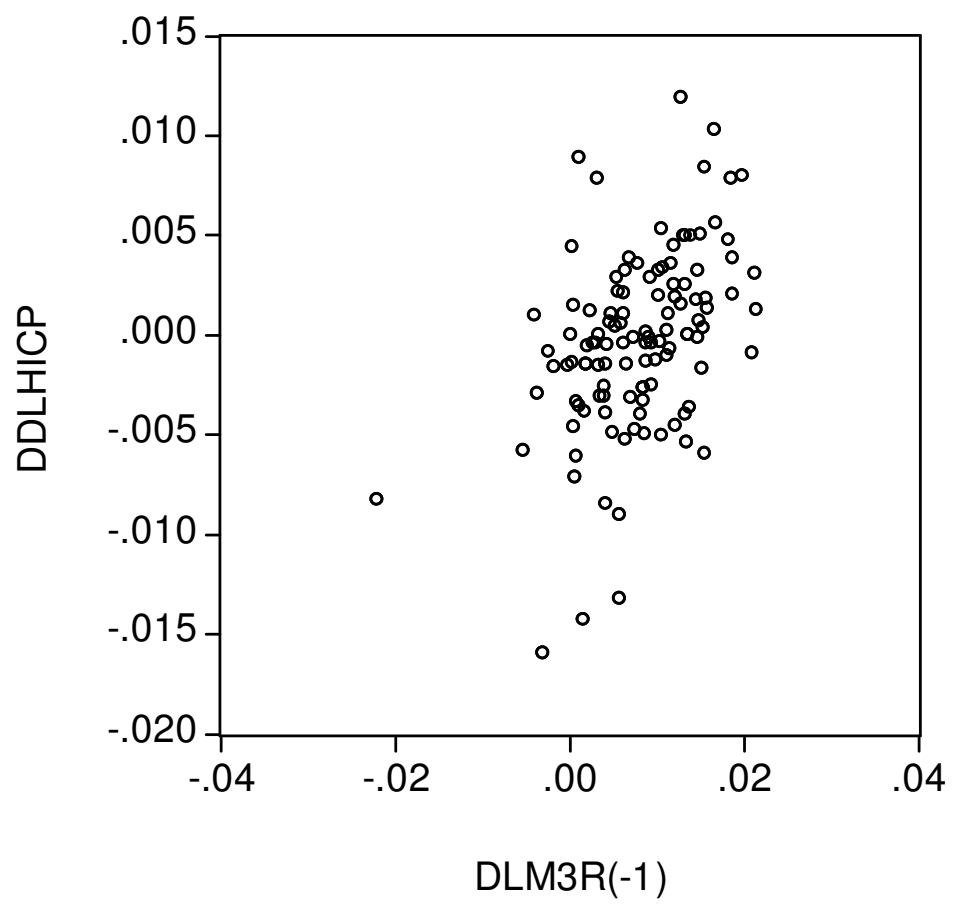

\section{A Markov Switching EC-VAR Model}

To further assess the robustness of the long-run relationship between money growth and the inflation rate over the sample period, we estimate the EC-VAR model with parameters subject to regime switches. Basically, we assume that all parameters switch between two states except for the covariance matrix of the residuals. From the previous analysis, we take as given the cointegrating relationships and we estimate the model again with the use of Markov chain Monte Carlo simulation methods. A preliminary analysis revealed that in the switching specification the coefficients on the second and third lag of the variables were insignificant. Therefore, the estimation includes only one lag of the endogenous variables. 
Table 3 reports the adjustment coefficients of the error terms in both states. In state 1, the adjustments to the error terms have the expected sign. In particular, the lagged term spread mainly affects the short term interest rate, while all other variables do not react significantly to it. All variables, except for the money growth acceleration, react positively to lagged changes in real money growth. In particular, inflation accelerates more strongly than in the linear case, 0.3 versus 0.18 in table 2 . The adjustment of money growth is about the same as in the linear case, -0.26 versus -0.22 in table 2 . Real money growth has also quite a strong effect on the short term (0.18) and the long term (0.11) interest rate, and on the output gap as well (0.18). Finally, the lagged output gap has a positive effect on the short term interest rate. State 2 is characterized by very rapid adjustments of interest rates to the spread and to real money growth. The short term and the long term interest rate adjust positively (0.77) and negatively (-0.29) to the lagged spread, while the other variables do not react significantly to it. Very interestingly, nominal money growth and inflation accelerate by about the same amount (-0.23 and 0.26 , respectively) as in state 1 to lagged real money growth. ${ }^{8}$ This confirms the robustness of the long-run relationship between money growth and inflation over the entire sample period found in the linear specification of the previous section. Both interest rates, on the other hand, adjust negatively to lagged real money growth in state 2 , the short term interest rate nearly five times larger in absolute value and the long-term interest rate twice as much as in state 1 . The lagged output gap does not affect other variables in this state.

Given that the adjustment of money growth and inflation to lagged changes in real money growth are nearly equal in the two states, we restrict these coefficients to be equal across regimes and re-estimate the Markov switching EC-VAR model. Figure 4 depicts the marginal posterior distributions of the adjustment coefficients obtained with this restriction. The figure confirms that state 2 (dotted lines) is mainly characterized by an almost immediate adjustment in interest rates to the lagged spread and also strong reactions of interest rates to lagged changes in real money growth.

\footnotetext{
${ }^{8}$ The standard deviations of both coefficients suggest marginal significance, which is confirmed by the confidence intervals (-0.58 0.03$)$ and (-0.07 0.56), respectively.
} 
Table 3: State-dependent error correction coefficients estimates of an EC-VAR(1) for the short rate, long rate, money growth, output gap and inflation in the euro area, 19752003. Standard errors are in parentheses.

\begin{tabular}{|l|c|c|c|c|}
\hline & & $\mathrm{R}-\mathrm{r}$ & $\Delta \mathrm{m}-\Delta \mathrm{p}$ & $\mathrm{X}$ \\
\hline$\Delta \mathrm{r}$ & state 1 & 0.13 & 0.18 & 0.14 \\
\hline & & $(0.5)$ & $(0.08)$ & $(0.06)$ \\
\hline & state 2 & 0.77 & -0.89 & 0.10 \\
\hline & & $(0.17)$ & $(0.18)$ & $(0.17)$ \\
\hline & state 1 & -0.01 & 0.11 & 0.03 \\
\hline & & $(0.04)$ & $(0.06)$ & $(0.04)$ \\
\hline & state 2 & -0.29 & -0.21 & -0.12 \\
\hline & & $(0.11)$ & $(0.13)$ & $(0.13)$ \\
\hline$\Delta(\Delta \mathrm{R})$ & state 1 & 0.03 & -0.26 & 0.07 \\
\hline & & $(0.04)$ & $(0.07)$ & $(0.05)$ \\
\hline & state 2 & 0.21 & -0.23 & -0.15 \\
\hline$\Delta \mathrm{x}$ & & $(0.13)$ & $(0.15)$ & $(0.17)$ \\
\hline & state 1 & 0.07 & 0.18 & -0.18 \\
\hline & & $(0.05)$ & $(0.08)$ & $(0.05)$ \\
\hline & state 2 & 0.05 & 0.15 & -0.06 \\
\hline$\Delta(\Delta \mathrm{p})$ & & $(0.14)$ & $(0.16)$ & $(0.13)$ \\
\hline & state 1 & 0.02 & 0.30 & 0.02 \\
\hline & & $(0.04)$ & $(0.07)$ & $(0.05)$ \\
\hline & state 2 & -0.13 & 0.26 & 0.20 \\
\hline & & $(0.14)$ & $(0.16)$ & $(0.14)$ \\
\hline
\end{tabular}

Figure 4: Marginal posterior distributions of the adjustment coefficients. Coefficient specific to state 1 (dashed) and coefficient specific to state 2 (dotted).
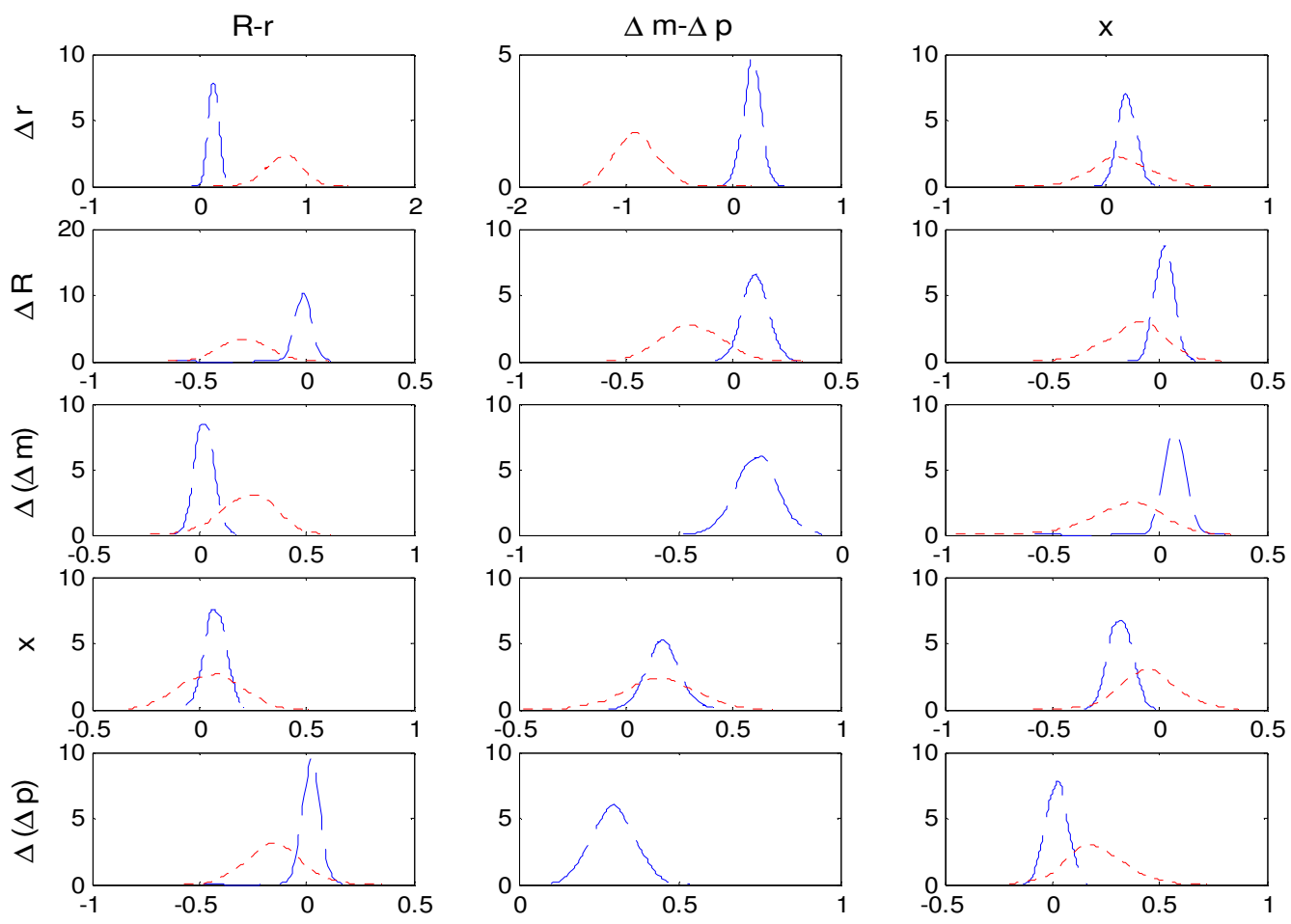
Figure 5: Posterior state probabilities along with both interest rates and the money growth and the inflation rate (in annualized values).

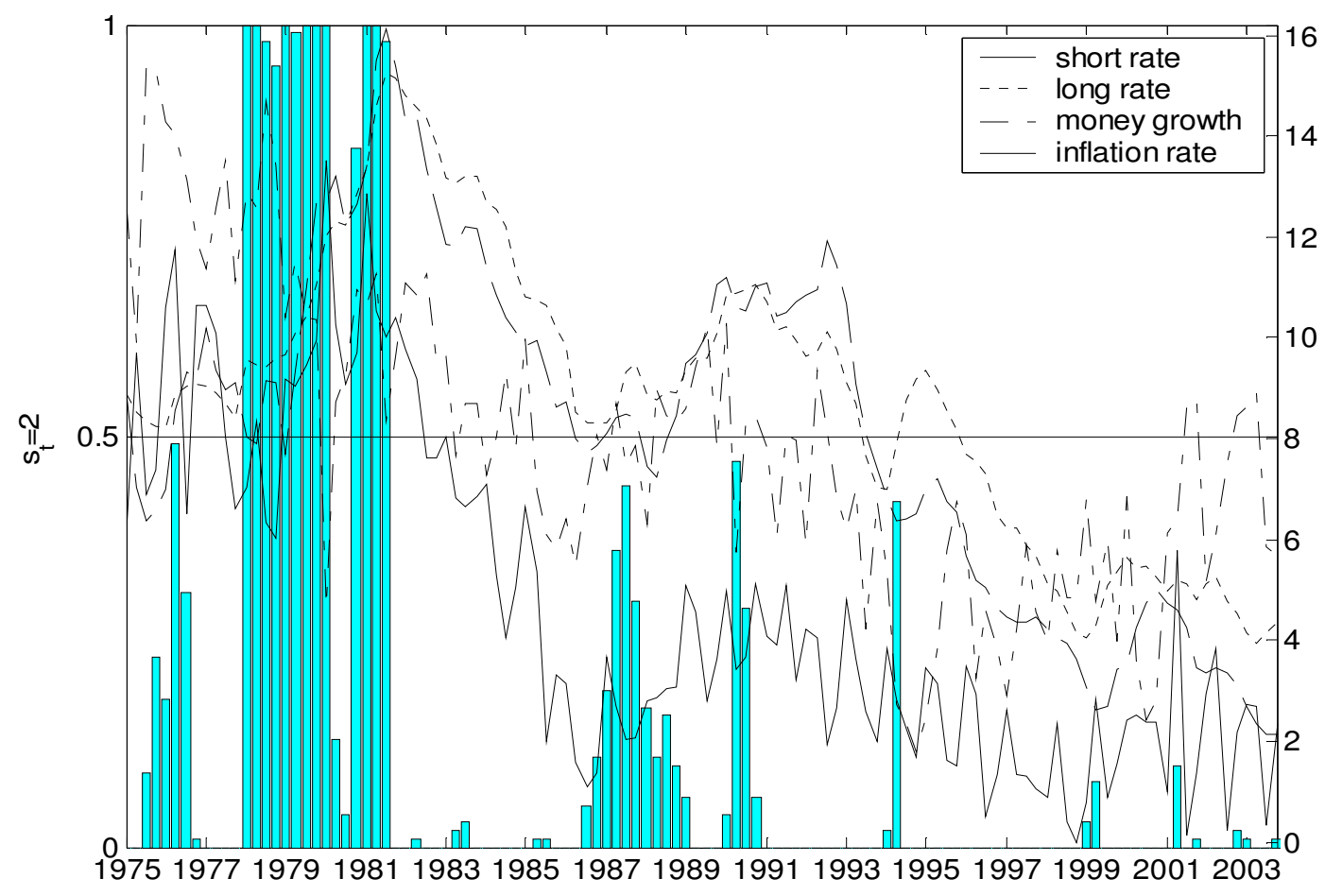

The relevance of the two states is confirmed in figure 5 which plots the posterior probabilities of state 2. This state prevailed from the first quarter of 1978 through the first quarter of 1980 and for another year from the last quarter of 1980 through the third quarter of 1981. Sharp and persistent increases in both interest rates along with accelerating rates of inflation and decreasing rates of money growth, hence decreasing real money growth, are characterizing this state (see also table 4). It is also interesting to note that changes in the short term interest rate are twice as volatile as in state 1 .

The impulse responses for state 1 (prevailing most of the time during the observation sample) are plotted in figure 6. We report a permanent increase, which is only marginally significant in the long-term, in both interest rates after a shock in nominal money growth. Inflation reacts significantly positively to a shock in nominal money growth, and likewise, money growth increases permanently after a shock in inflation. ${ }^{9}$ The output gap reacts transitorily to shocks in money growth and to shocks in inflation, positively (without significance) in the first case and negatively in the second case. Finally shocks in the output gap have a transitory positive

\footnotetext{
${ }^{9}$ See footnote 5 .
} 
effect on the short-term interest rate and shocks in both interest rates affect the output gap transitorily positively.

Table 4: Mean and standard deviation (in parentheses) of the variables in the two regimes (annualized figures).

\begin{tabular}{|l|c|c|c|c|c|}
\hline Levels & Regime 1 & $\begin{array}{c}\text { Regime 2 } \\
\text { 1978Q1-1980Q1 } \\
\text { 1980Q4-1981Q3 }\end{array}$ & $\begin{array}{c}\text { First } \\
\text { Differences }\end{array}$ & Regime 1 & $\begin{array}{c}\text { Regime 2 } \\
\text { 1978Q1-1980Q1 } \\
\text { 1980Q4-1981Q3 }\end{array}$ \\
\hline & & & & & \\
\hline $\mathrm{r}$ & 7.81 & 11.18 & $\Delta \mathrm{r}$ & -0.14 & 0.58 \\
\hline $\mathrm{R}$ & $(3.25)$ & $(2.87)$ & & $(0.56)$ & $(1.09)$ \\
\hline & 8.58 & 11.34 & $\Delta \mathrm{R}$ & -0.11 & 0.51 \\
\hline$\Delta \mathrm{m}$ & $(2.80)$ & $(2.08)$ & & $(0.39)$ & $(0.42)$ \\
\hline & $(2.52$ & 10.93 & $\Delta(\Delta \mathrm{m})$ & $(0.01)$ & $(-0.57)$ \\
\hline$\Delta \mathrm{p}$ & 4.09 & $(2.49)$ & & $(1.76)$ & $(2.25)$ \\
\hline & $(2.89)$ & $(2.21)$ & & -0.12 & 0.60 \\
\hline$\Delta \mathrm{m}-\Delta \mathrm{p}$ & 3.43 & 1.55 & $\Delta(\Delta \mathrm{m}-\Delta \mathrm{p})$ & 0.12 & $(1.84)$ \\
\hline & $(2.27)$ & $(4.49)$ & & $(2.66)$ & $(3.65)$ \\
\hline
\end{tabular}

Note that except for real money growth the variables in levels are non-stationary. Thus, means and standard deviations in these cases should be considered as purely descriptive measures and not as estimates of the corresponding (non-existing) population moments.

Figure 6: Accumulated impulse responses in state 1 along with the $95 \%$ confidence interval.

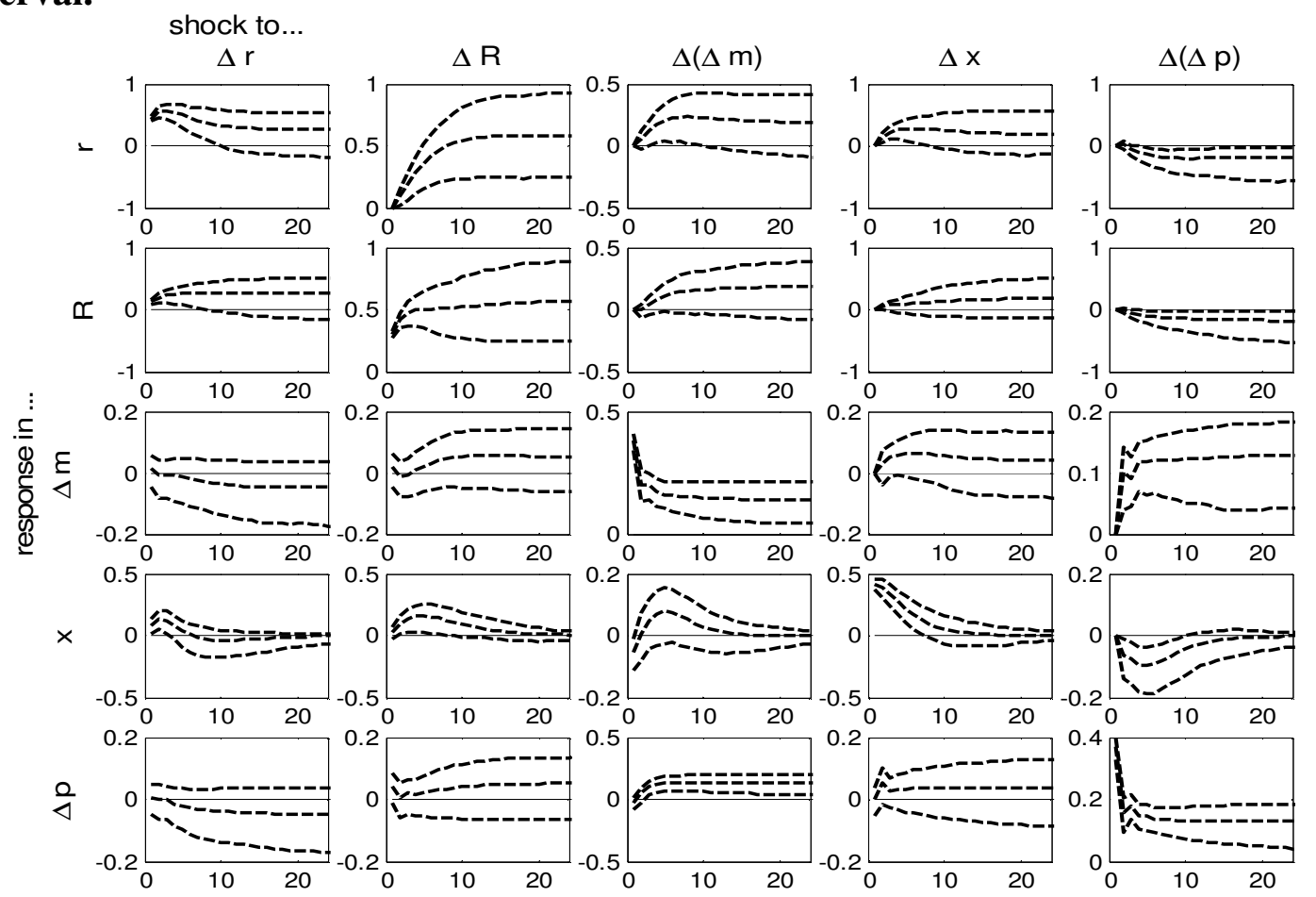


Figure 7: Accumulated impulse responses in state 2 along with the 95\% confidence interval.
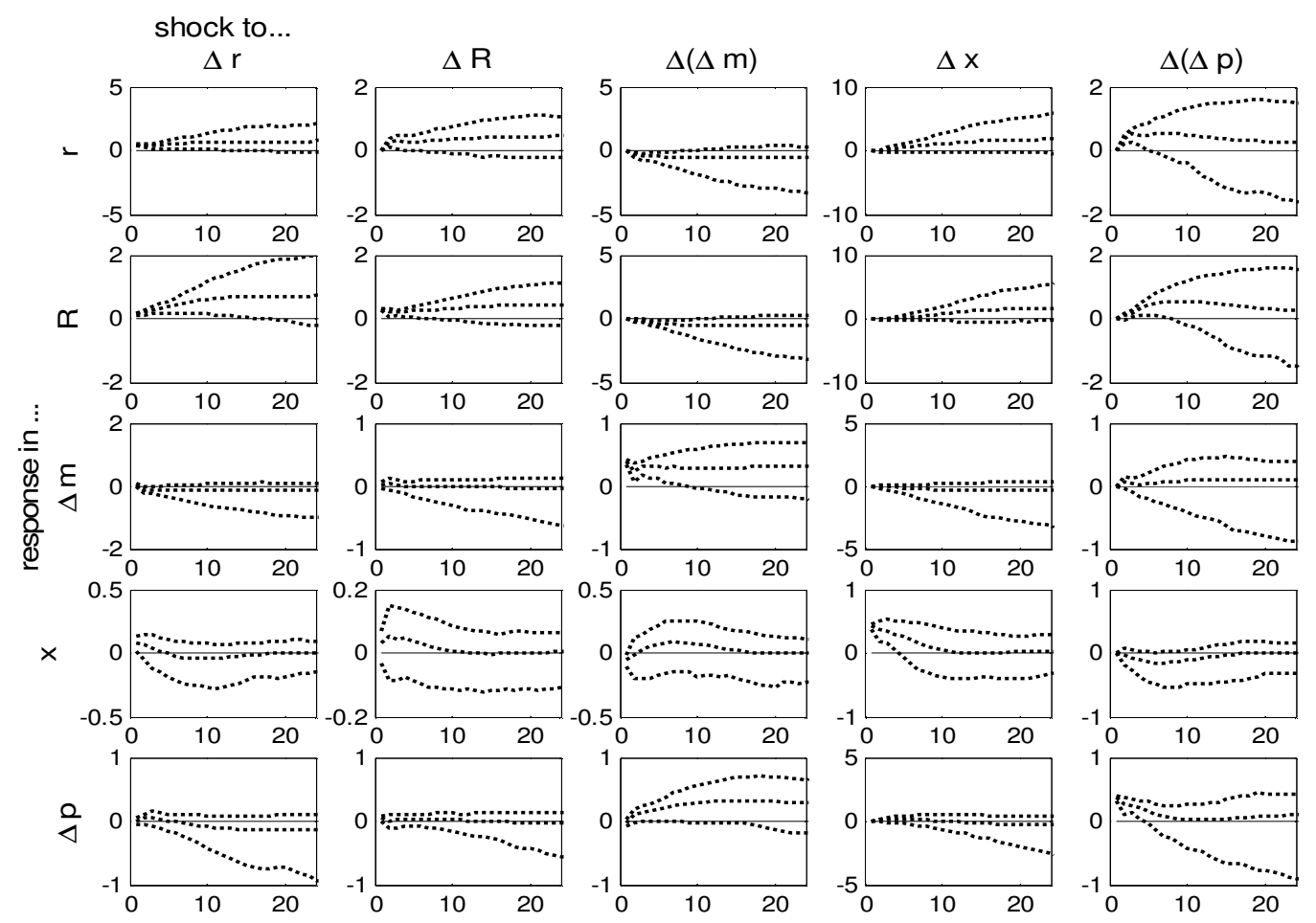

Figure 7 plots the impulse responses for the second state. Both interest rates react negatively to shocks in nominal money growth and positively to shocks in inflation. These patterns reflect the characteristics of the second state. Sharply rising and volatile interest rates combined with increasing levels of inflation. The negative reaction to changes in nominal money growth comes from the decrease in real money growth, reflecting tight monetary policy, while interest rates and inflation were still rising. All other impulse responses are mainly insignificant. Worth mentioning are the negative reaction of the output gap to a shock in inflation and the positive reaction of inflation to a shock in money growth. Although both reactions are nearly insignificant also in the short turn, they have the correct sign.

The variance decompositions obtained in state 1 are plotted in figure 8 . Basically, the results of the linear model are confirmed. In the short run, for both interest rates the forecast error variance is dominated by own shocks, while in the long run, shocks to the long-term interest rate dominate the error variance in both interest rates. Shocks to the long-term interest rate also explain a remarkable fraction (nearly 20 percent) of the forecast error variance in the output gap. The main share of the forecast error variance of nominal money growth is attributable to own shocks (50 percent), while shocks to inflation explain about 28 percent in 
the long run. Shocks to money growth explain 16 percent of the forecast error in inflation after one year and 25 percent after two years. In the long run, the share increases to one third, which confirms the monetary phenomenon of inflation.

In state 2, the impulse responses revealed that shocks are mainly absorbed by interest rates changes. This is also reflected in the variance decompositions (see figure 9). A sizeable share of the forecast error variance in both interest rates is explained by shocks to nominal money growth, to the output gap and to inflation, rapidly increasing to the long run level. Interestingly, a major share of the forecast error variance of the other two financial variables in the system, money growth and inflation, is also attributable to shocks in the output gap. Both shares increase from, respectively, 14 percent and 16 percent after one year to 33 percent in the long run. Still, shocks in money growth explain about 33 percent of the error variance in the inflation rate in the long run.

Figure 8: Variance decomposition in state 1, EC-VAR(1), 1975-2003, mean estimate with $95 \%$ confidence interval.

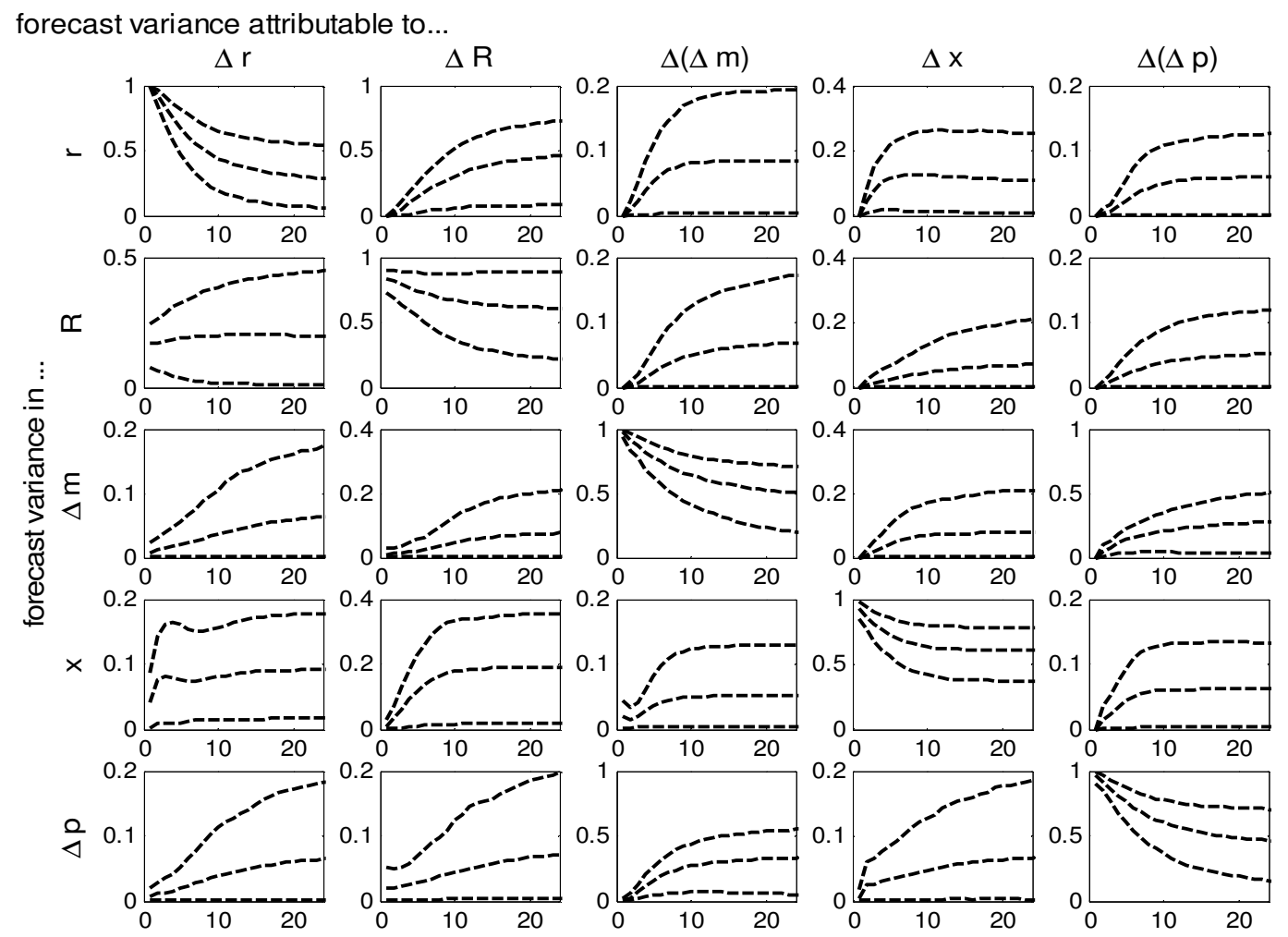


Figure 9: Variance decomposition in state 2, EC-VAR(1), 1975-2003, mean estimate with 95\% confidence interval.

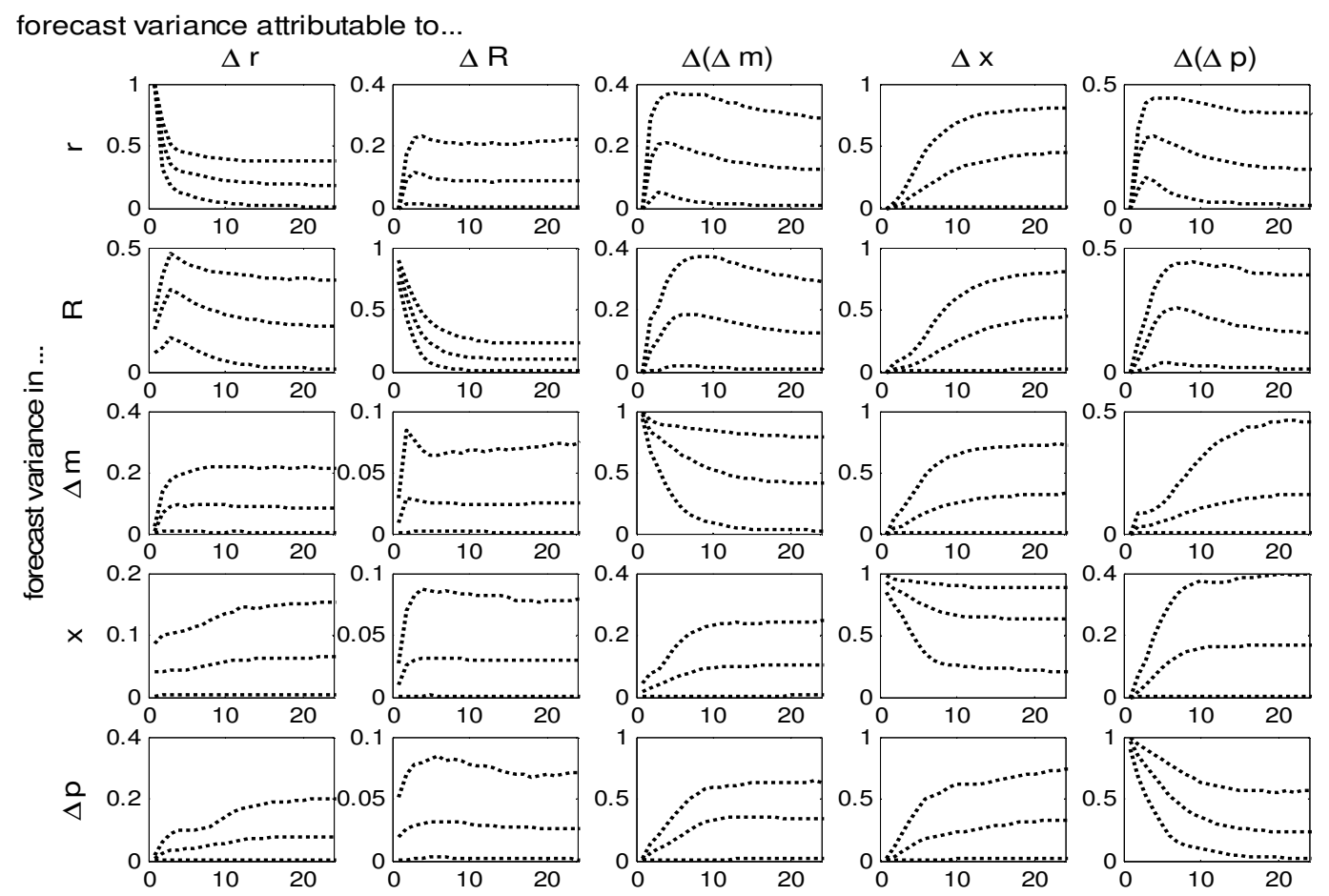

\section{Summary and Conclusions}

There is mixed recent empirical evidence concerning the role of the money stock M3 as an indicator for future inflation and correspondingly current monetary policy. On the one hand, the data since 2001 raise a substantial doubt about the existence of a stable long run money demand function, and the predictive power of money growth or money growth corrected for inflation (real money growth?) seemed to be only minor. On the other hand, this negative evidence for the relevance of M3 in the euro area is questioned by recent papers concentrating on the relationship between trend inflation and money growth, both approximated by HPfiltered values. This paper confirms the results of those recent studies using a different econometric methodology. Instead of relying on constructed variables, such as core money growth, trend inflation, or real money and price gaps, and on a specific structural model for inflation dynamics, relying on a stable long run money demand function, we analyse the short and long run interrelationship between inflation and money growth in an error correction framework, also including the output gap (or GDP growth) and short and long term interest rates. 
In this context, different degrees of integration of the variables are taken into account: unit root and stationarity tests indicate that prices and money are $\mathrm{I}(2)$, that both interest rates, a short term and a long term interest rate, are I(1) variables. The output gap enters the analysis, of course, as a stationary series. In addition, a stable long run money demand function does not seem to be present when data of the most recent years are included in the analysis. We consider the short and long run interrelationship between inflation and nominal money growth, which are indicated to be cointegrated, in a five variable error correction model with and without Markov regime switches. The results of the linear model and the first regime prevailing most of the sample period in the nonlinear model are essentially equal. We find robust cointegration between nominal money growth and inflation with strong error correction in both variables. In the long run, shocks in M3-growth account for 33 percent to 40 percent of the inflation forecast error variance. The effects of output gap and interest rate shocks on inflation are mainly transitory and their forecast error variance shares are negligible at medium term horizons.

There is evidence for a second regime prevailing at the end of the seventies and beginning of the eighties which relates to periods of high interest rate and inflation rate levels and decreasing, even contracting, rates in real money growth. Overall, we present firm evidence for a stable dynamic relationship between money growth and inflation which implies that the deviation of real money growth from its long run average is a good indicator of future inflation acceleration or deceleration. This finding, of course provides evidence in favour of the recently de-emphasised first pillar of the ECB strategy. Nevertheless, according to our results and given a historical average real money growth rate of 3,2\%, an M3-growth rate of slightly above $5 \%$ is compatible with a non-accelerating average rate of inflation of $2 \%$. 


\section{References}

Bruggeman, A. P. Donati and A. Warne (2003), Is the Demand for Euro Area M3 Stable?, ECB Working Paper No. 255.

Carstensen, K (2004), Is European Money Demand Stable?, Kiel Working Paper No. 1179.

Coenen, G. and Vega, J.-L. (1999), The demand for M3 in the Euro area, ECB Working Paper No. 6.

Engsted, T., Gonzalo, J. and Haldrup, N. (1997), Testing for Multicointegration, Economics Letters 56, 259-266.

Gerlach, S. (2004), The two pillars of the European Central Bank, Economic Policy, 389-439.

Gerlach, S. and L. O. E. Svensson, Money and Inflation in the Euro Area: a Case for Monetary Indicators?, Journal of Monetary Economics 50, 1649-72.

von Hagen, J. (2004), Hat die Geldmenge ausgedient?, Perspektiven der Wirtschaftspolitik 5(4), 423-53.

Haldrup, N. (1994), The Asymptotics of Single-Equation Cointegration Regression with I(1) and I(2) Variables, Journal of Econometrics 63, 152-181.

Hamilton, J.D. (1994), Time Series Analysis, Princeton University Press.

Holtemöller, O. (2004), A monetary vector error correction model of the Euro area and implications for monetary policy, Empirical Economics 29, 553-574.

Neumann, M. J. M. (2003), The European Central Bank's First Pillar Reassessed, Working Paper March 03, IIW Bonn University.

Neumann, M. J. M. and C. Greiber (2004), Inflation and Core Money Growth in The Euro Area, Deutsche Bundesbank Discussion Paper Series 1 No. 36/2004March 03, IIW Bonn University.

Nicoletti Altimari, S. (2001), Does Money Lead Inflation in the Euro Area?, ECB Working Paper No.63.

Kaufmann, S. and M.T. Valderrama (2004), Modelling Credit Aggregates, OeNB Working Paper No. 90.

Litterman, R.B. (1986), Forecasting with Bayesian vector autoregressions - Five years of experience, Journal of Business \& Economic Statistics 4, 25-38.

Reinsel, G. C. and S. K. Ahn (1992), Vector Autoregressive Models with Unit Roots and Reduced Rank Structure: Estimation, Likelihood Ratio Tests, and Forecasting, Journal of Time Series Analysis 13, 353-75. 


\section{Index of Working Papers:}

\begin{tabular}{llrl}
$\begin{array}{l}\text { August 28, } \\
1990\end{array}$ & Pauer Franz & $1^{1{ }^{1}}$ & $\begin{array}{l}\text { Hat Böhm-Bawerk Recht gehabt? Zum Zu- } \\
\text { sammenhang zwischen Handelsbilanzpas- } \\
\text { sivum und Budgetdefizit in den USA }\end{array}$ \\
\hline $\begin{array}{l}\text { March 20, } \\
1991\end{array}$ & Backé Peter & $2^{1)}$ & $\begin{array}{l}\text { Ost- und Mitteleuropa auf dem Weg zur } \\
\text { Marktwirtschaft - Anpassungskrise 1990 }\end{array}$ \\
\hline $\begin{array}{l}\text { March 14, } \\
1991\end{array}$ & Pauer Franz & $3^{1)}$ & $\begin{array}{l}\text { Die Wirtschaft Österreichs im Vergleich zu } \\
\text { den EG-Staaten - eine makroökonomische } \\
\text { Analyse für die 80er Jahre }\end{array}$ \\
\hline May 28, 1991 & Mauler Kurt & $4^{1)}$ & $\begin{array}{l}\text { The Soviet Banking Reform } \\
\text { July 16, 1991 }\end{array}$ \\
& Pauer Franz & $5^{1)}$ & $\begin{array}{l}\text { Die Auswirkungen der Finanzmarkt- und } \\
\text { Kapitalverkehrsliberalisierung auf die } \\
\text { Wirtschaftsentwicklung und Wirtschaftspolitik } \\
\text { in Norwegen, Schweden, Finnland und } \\
\text { Großbritannien - mögliche Konsequenzen für } \\
\text { Österreich }\end{array}$ \\
\hline
\end{tabular}

\begin{tabular}{lll}
\hline August 1, $1991 \quad$ Backé Peter & $6^{1)}$ & Zwei Jahre G-24-Prozess: Bestandsauf- \\
& nahme und Perspektiven unter besonderer \\
& Berücksichtigung makroökonomischer \\
& Unterstützungsleistungen ${ }^{4}$
\end{tabular}

\begin{tabular}{|c|c|c|c|}
\hline August 8, 1991 & Holzmann Robert & $7^{1)}$ & $\begin{array}{l}\text { Die Finanzoperationen der öffentlichen } \\
\text { Haushalte der Reformländer CSFR, Polen } \\
\text { und Ungarn: Eine erste quantitative Analyse }\end{array}$ \\
\hline $\begin{array}{l}\text { January 27, } \\
1992\end{array}$ & Pauer Franz & $8^{11}$ & $\begin{array}{l}\text { Erfüllung der Konvergenzkriterien durch die } \\
\text { EG-Staaten und die EG-Mitgliedswerber } \\
\text { Schweden und Österreich }{ }^{5}\end{array}$ \\
\hline
\end{tabular}

\begin{tabular}{|c|c|c|c|}
\hline $\begin{array}{l}\text { October 12, } \\
1992\end{array}$ & $\begin{array}{l}\text { Hochreiter Eduard } \\
\text { (Editor) }\end{array}$ & $9^{1)}$ & $\begin{array}{l}\text { Alternative Strategies For Overcoming the } \\
\text { Current Output Decline of Economies in } \\
\text { Transition }\end{array}$ \\
\hline
\end{tabular}

\begin{tabular}{ll}
\hline $\begin{array}{l}\text { November 10, } \\
1992\end{array}$ & $\begin{array}{l}\text { Hochreiter Eduard and } \\
\text { Winckler Georg }\end{array}$ \\
\hline
\end{tabular}

1) vergriffen (out of print)

2) In abgeänderter Form erschienen in Berichte und Studien Nr. 4/1990, S 74 ff

3) In abgeänderter Form erschienen in Berichte und Studien Nr. 4/1991, S 44 ff

4) In abgeänderter Form erschienen in Berichte und Studien Nr. 3/1991, S 39 ff

5) In abgeänderter Form erschienen in Berichte und Studien Nr. 1/1992, S 54 ff 


\begin{tabular}{|c|c|c|c|}
\hline March 12, 1993 & $\begin{array}{l}\text { Hochreiter Eduard } \\
\text { (Editor) }\end{array}$ & 11 & $\begin{array}{l}\text { The Impact of the Opening-up of the East on } \\
\text { the Austrian Economy - A First Quantitative } \\
\text { Assessment }\end{array}$ \\
\hline June 8,1993 & Anulova Guzel & 12 & The Scope for Regional Autonomy in Russia \\
\hline July 14,1993 & Mundell Robert & 13 & $\begin{array}{l}\text { EMU and the International Monetary Sy- } \\
\text { stem: A Transatlantic Perspective }\end{array}$ \\
\hline $\begin{array}{l}\text { November 29, } \\
1993\end{array}$ & Hochreiter Eduard & 14 & $\begin{array}{l}\text { Austria's Role as a Bridgehead Between } \\
\text { East and West }\end{array}$ \\
\hline March 8, 1994 & $\begin{array}{l}\text { Hochreiter Eduard } \\
\text { (Editor) }\end{array}$ & 15 & Prospects for Growth in Eastern Europe \\
\hline June 8,1994 & Mader Richard & 16 & A Survey of the Austrian Capital Market \\
\hline $\begin{array}{l}\text { September 1, } \\
1994\end{array}$ & $\begin{array}{l}\text { Andersen Palle and } \\
\text { Dittus Peter }\end{array}$ & 17 & $\begin{array}{l}\text { Trade and Employment: Can We Afford } \\
\text { Better Market Access for Eastern Europe? }\end{array}$ \\
\hline $\begin{array}{l}\text { November 21, } \\
1994\end{array}$ & Rautava Jouko & $18^{1)}$ & $\begin{array}{l}\text { Interdependence of Politics and Economic } \\
\text { Development: Financial Stabilization in } \\
\text { Russia }\end{array}$ \\
\hline January 30, 1995 & $\begin{array}{l}\text { Hochreiter Eduard } \\
\text { (Editor) }\end{array}$ & 19 & $\begin{array}{l}\text { Austrian Exchange Rate Policy and } \\
\text { European Monetary Integration - Selected } \\
\text { Issues }\end{array}$ \\
\hline October 3, 1995 & Groeneveld Hans & 20 & $\begin{array}{l}\text { Monetary Spill-over Effects in the ERM: The } \\
\text { Case of Austria, a Former Shadow Member }\end{array}$ \\
\hline $\begin{array}{l}\text { December 6, } \\
1995\end{array}$ & Frydman Roman et al & 21 & $\begin{array}{l}\text { Investing in Insider-dominated Firms: A } \\
\text { Study of Voucher Privatization Funds in } \\
\text { Russia }\end{array}$ \\
\hline March 5, 1996 & Wissels Rutger & 22 & $\begin{array}{l}\text { Recovery in Eastern Europe: Pessimism } \\
\text { Confounded? }\end{array}$ \\
\hline June 25,1996 & Pauer Franz & 23 & $\begin{array}{l}\text { Will Asymmetric Shocks Pose a Serious } \\
\text { Problem in EMU? }\end{array}$ \\
\hline $\begin{array}{l}\text { September 19, } \\
1997\end{array}$ & Koch Elmar B. & 24 & $\begin{array}{l}\text { Exchange Rates and Monetary Policy in } \\
\text { Central Europe - a Survey of Some Issues }\end{array}$ \\
\hline April 15, 1998 & Weber Axel A. & 25 & $\begin{array}{l}\text { Sources of Currency Crises: An Empirical } \\
\text { Analysis }\end{array}$ \\
\hline
\end{tabular}




\begin{tabular}{|c|c|c|c|}
\hline May 28,1998 & $\begin{array}{l}\text { Brandner Peter, } \\
\text { Diebalek Leopold and } \\
\text { Schuberth Helene }\end{array}$ & 26 & $\begin{array}{l}\text { Structural Budget Deficits and Sustainability } \\
\text { of Fiscal Positions in the European Union }\end{array}$ \\
\hline June 15,1998 & $\begin{array}{l}\text { Canzeroni Matthew, } \\
\text { Cumby Robert, Diba } \\
\text { Behzad and Eudey } \\
\text { Gwen }\end{array}$ & 27 & $\begin{array}{l}\text { Trends in European Productivity: } \\
\text { Implications for Real Exchange Rates, Real } \\
\text { Interest Rates and Inflation Differentials }\end{array}$ \\
\hline June 20,1998 & MacDonald Ronald & 28 & $\begin{array}{l}\text { What Do We Really Know About Real } \\
\text { Exchange Rates? }\end{array}$ \\
\hline June 30, 1998 & $\begin{array}{l}\text { Campa José and Wolf } \\
\text { Holger }\end{array}$ & 29 & $\begin{array}{l}\text { Goods Arbitrage and Real Exchange Rate } \\
\text { Stationarity }\end{array}$ \\
\hline July 3,1998 & Papell David H. & 30 & $\begin{array}{l}\text { The Great Appreciation, the Great } \\
\text { Depreciation, and the Purchasing Power } \\
\text { Parity Hypothesis }\end{array}$ \\
\hline July 20,1998 & Chinn Menzie David & 31 & $\begin{array}{l}\text { The Usual Suspects? Productivity and } \\
\text { Demand Shocks and Asia-Pacific Real } \\
\text { Exchange Rates }\end{array}$ \\
\hline July 30,1998 & $\begin{array}{l}\text { Cecchetti Stephen G., } \\
\text { Mark Nelson C., } \\
\text { Sonora Robert }\end{array}$ & 32 & $\begin{array}{l}\text { Price Level Convergence Among United } \\
\text { States Cities: Lessons for the European } \\
\text { Central Bank }\end{array}$ \\
\hline $\begin{array}{l}\text { September 30, } \\
1998\end{array}$ & $\begin{array}{l}\text { Christine Gartner, Gert } \\
\text { Wehinger }\end{array}$ & 33 & $\begin{array}{l}\text { Core Inflation in Selected European Union } \\
\text { Countries }\end{array}$ \\
\hline $\begin{array}{l}\text { November 5, } \\
1998\end{array}$ & $\begin{array}{l}\text { José Viñals and Juan } \\
\text { F. Jimeno }\end{array}$ & 34 & $\begin{array}{l}\text { The Impact of EMU on European } \\
\text { Unemployment }\end{array}$ \\
\hline $\begin{array}{l}\text { December 11, } \\
1998\end{array}$ & $\begin{array}{l}\text { Helene Schuberth and } \\
\text { Gert Wehinger }\end{array}$ & 35 & $\begin{array}{l}\text { Room for Manoeuvre of Economic Policy in } \\
\text { the EU Countries - Are there Costs of } \\
\text { Joining EMU? }\end{array}$ \\
\hline $\begin{array}{l}\text { December 21, } \\
1998\end{array}$ & $\begin{array}{l}\text { Dennis C. Mueller and } \\
\text { Burkhard Raunig }\end{array}$ & 36 & $\begin{array}{l}\text { Heterogeneities within Industries and } \\
\text { Structure-Performance Models }\end{array}$ \\
\hline May 21, 1999 & $\begin{array}{l}\text { Alois Geyer and } \\
\text { Richard Mader }\end{array}$ & 37 & $\begin{array}{l}\text { Estimation of the Term Structure of Interest } \\
\text { Rates - A Parametric Approach }\end{array}$ \\
\hline July 29, 1999 & $\begin{array}{l}\text { José Viñals and Javier } \\
\text { Vallés }\end{array}$ & 38 & $\begin{array}{l}\text { On the Real Effects of Monetary Policy: A } \\
\text { Central Banker's View }\end{array}$ \\
\hline $\begin{array}{l}\text { December 20, } \\
1999\end{array}$ & $\begin{array}{l}\text { John R. Freeman, Jude } \\
\text { C. Hays and Helmut } \\
\text { Stix }\end{array}$ & 39 & $\begin{array}{l}\text { Democracy and Markets: The Case of } \\
\text { Exchange Rates }\end{array}$ \\
\hline
\end{tabular}




\begin{tabular}{|c|c|c|c|}
\hline March 01, 2000 & $\begin{array}{l}\text { Eduard Hochreiter and } \\
\text { Tadeusz Kowalski }\end{array}$ & 40 & $\begin{array}{l}\text { Central Banks in European Emerging } \\
\text { Market } \\
\text { Economies in the 1990s }\end{array}$ \\
\hline March 20, 2000 & Katrin Wesche & 41 & $\begin{array}{l}\text { Is there a Credit Channel in Austria? } \\
\text { The Impact of Monetary Policy on Firms' } \\
\text { Investment Decisions }\end{array}$ \\
\hline June 20,2000 & $\begin{array}{l}\text { Jarko Fidrmuc and Jan } \\
\text { Fidrmuc }\end{array}$ & 42 & $\begin{array}{l}\text { Integration, Disintegration and Trade in } \\
\text { Europe: Evolution of Trade Relations During } \\
\text { the 1990s }\end{array}$ \\
\hline March 06, 2001 & Marc Flandreau & 43 & $\begin{array}{l}\text { The Bank, the States, and the Market, } \\
\text { A Austro-Hungarian Tale for Euroland, } \\
1867-1914\end{array}$ \\
\hline May 01, 2001 & Otmar Issing & 44 & $\begin{array}{l}\text { The Euro Area and the Single Monetary } \\
\text { Policy }\end{array}$ \\
\hline May 18,2001 & Sylvia Kaufmann & 45 & $\begin{array}{l}\text { Is there an asymmetric effect of monetary } \\
\text { policy over time? A Bayesian analysis using } \\
\text { Austrian data. }\end{array}$ \\
\hline May 31, 2001 & $\begin{array}{l}\text { Paul De Grauwe and } \\
\text { Marianna Grimaldi }\end{array}$ & 46 & $\begin{array}{l}\text { Exchange Rates, Prices and Money. A Long } \\
\text { Run Perspective }\end{array}$ \\
\hline June 25,2001 & $\begin{array}{l}\text { Vítor Gaspar, } \\
\text { Gabriel Perez-Quiros } \\
\text { and Jorge Sicilia }\end{array}$ & 47 & $\begin{array}{l}\text { The ECB Monetary Strategy and the Money } \\
\text { Market }\end{array}$ \\
\hline July 27,2001 & David T. Llewellyn & 48 & A Regulatory Regime For Financial Stability \\
\hline August 24, 2001 & $\begin{array}{l}\text { Helmut Elsinger and } \\
\text { Martin Summer }\end{array}$ & 49 & $\begin{array}{l}\text { Arbitrage Arbitrage and Optimal Portfolio } \\
\text { Choice with Financial Constraints }\end{array}$ \\
\hline $\begin{array}{l}\text { September 1, } \\
2001\end{array}$ & $\begin{array}{l}\text { Michael D. Goldberg } \\
\text { and Roman Frydman }\end{array}$ & 50 & $\begin{array}{l}\text { Macroeconomic Fundamentals and the } \\
\text { DM/\$ Exchange Rate: Temporal Instability } \\
\text { and the Monetary Model }\end{array}$ \\
\hline $\begin{array}{l}\text { September 8, } \\
2001\end{array}$ & $\begin{array}{l}\text { Vittorio Corbo, } \\
\text { Oscar Landerretche } \\
\text { and Klaus } \\
\text { Schmidt-Hebbel }\end{array}$ & 51 & $\begin{array}{l}\text { Assessing Inflation Targeting after a Decade } \\
\text { of World Experience }\end{array}$ \\
\hline $\begin{array}{l}\text { September 25, } \\
2001\end{array}$ & $\begin{array}{l}\text { Kenneth N. Kuttner and } \\
\text { Adam S. Posen }\end{array}$ & 52 & $\begin{array}{l}\text { Beyond Bipolar: A Three-Dimensional } \\
\text { Assessment of Monetary Frameworks }\end{array}$ \\
\hline
\end{tabular}




\begin{tabular}{|c|c|c|c|}
\hline October 1, 2001 & $\begin{array}{l}\text { Luca Dedola and } \\
\text { Sylvain Leduc }\end{array}$ & 53 & $\begin{array}{l}\text { Why Is the Business-Cycle Behavior of } \\
\text { Fundamentals Alike Across Exchange-Rate } \\
\text { Regimes? }\end{array}$ \\
\hline October 10, 2001 & Tommaso Monacelli & 54 & $\begin{array}{l}\text { New International Monetary Arrangements } \\
\text { and the Exchange Rate }\end{array}$ \\
\hline $\begin{array}{l}\text { December 3, } \\
2001\end{array}$ & $\begin{array}{l}\text { Peter Brandner, } \\
\text { Harald Grech and } \\
\text { Helmut Stix }\end{array}$ & 55 & $\begin{array}{l}\text { The Effectiveness of Central } \\
\text { Intervention in the EMS: The Post } 1993 \\
\text { Experience }\end{array}$ \\
\hline January 2, 2002 & Sylvia Kaufmann & 56 & $\begin{array}{l}\text { Asymmetries in Bank Lending Behaviour. } \\
\text { Austria During the } 1990 \text { s }\end{array}$ \\
\hline January 7,2002 & Martin Summer & 57 & Banking Regulation and Systemic Risk \\
\hline January 28, 2002 & Maria Valderrama & 58 & $\begin{array}{l}\text { Credit Channel and Investment Behavior in } \\
\text { Austria: A Micro-Econometric Approach }\end{array}$ \\
\hline $\begin{array}{l}\text { February 18, } \\
2002\end{array}$ & $\begin{array}{l}\text { Gabriela de Raaij } \\
\text { and Burkhard Raunig }\end{array}$ & 59 & $\begin{array}{l}\text { Evaluating Density Forecasts with an } \\
\text { Application to Stock Market Returns }\end{array}$ \\
\hline $\begin{array}{l}\text { February 25, } \\
2002\end{array}$ & $\begin{array}{l}\text { Ben R. Craig and } \\
\text { Joachim G. Keller }\end{array}$ & 60 & $\begin{array}{l}\text { The Empirical Performance of Option Based } \\
\text { Densities of Foreign Exchange }\end{array}$ \\
\hline $\begin{array}{l}\text { February 28, } \\
2002\end{array}$ & $\begin{array}{l}\text { Peter Backé, } \\
\text { Jarko Fidrmuc, Thomas } \\
\text { Reininger and Franz } \\
\text { Schardax }\end{array}$ & 61 & $\begin{array}{l}\text { Price Dynamics in Central and Eastern } \\
\text { European EU Accession Countries }\end{array}$ \\
\hline April 8, 2002 & $\begin{array}{l}\text { Jesús Crespo- } \\
\text { Cuaresma, } \\
\text { Maria Antoinette Dimitz } \\
\text { and Doris Ritzberger- } \\
\text { Grünwald }\end{array}$ & 62 & Growth, Convergence and EU Membership \\
\hline May 29, 2002 & Markus Knell & 63 & $\begin{array}{l}\text { Wage Formation in Open Economies and } \\
\text { the Role of Monetary and Wage-Setting } \\
\text { Institutions }\end{array}$ \\
\hline June 19, 2002 & $\begin{array}{l}\text { Sylvester C.W. } \\
\text { Eijffinger } \\
\text { (comments by: José } \\
\text { Luis Malo de Molina } \\
\text { and by Franz Seitz) }\end{array}$ & 64 & $\begin{array}{l}\text { The Federal Design of a Central Bank } \\
\text { in a Monetary Union: The Case of the } \\
\text { European System of Central Banks }\end{array}$ \\
\hline
\end{tabular}




\begin{tabular}{|c|c|c|c|}
\hline July 1,2002 & $\begin{array}{l}\text { Sebastian Edwards and } \\
\text { I. Igal Magendzo } \\
\text { (comments by Luis } \\
\text { Adalberto Aquino } \\
\text { Cardona and by Hans } \\
\text { Genberg) }\end{array}$ & 65 & $\begin{array}{l}\text { Dollarization and Economic Performance: } \\
\text { What Do We Really Know? }\end{array}$ \\
\hline July 10,2002 & $\begin{array}{l}\text { David Begg } \\
\text { (comment by Peter } \\
\text { Bofinger) }\end{array}$ & 66 & $\begin{array}{l}\text { Growth, Integration, and Macroeconomic } \\
\text { Policy Design: Some Lessons for Latin } \\
\text { America }\end{array}$ \\
\hline July 15,2002 & $\begin{array}{l}\text { Andrew Berg, } \\
\text { Eduardo Borensztein, } \\
\text { and Paolo Mauro } \\
\text { (comment by Sven } \\
\text { Arndt) }\end{array}$ & 67 & $\begin{array}{l}\text { An Evaluation of Monetary Regime Options } \\
\text { for Latin America }\end{array}$ \\
\hline July 22, 2002 & $\begin{array}{l}\text { Eduard Hochreiter, } \\
\text { Klaus Schmidt-Hebbel } \\
\text { and Georg Winckler } \\
\text { (comments by Lars } \\
\text { Jonung and George } \\
\text { Tavlas) }\end{array}$ & 68 & $\begin{array}{l}\text { Monetary Union: European Lessons, Latin } \\
\text { American Prospects }\end{array}$ \\
\hline July 29, 2002 & $\begin{array}{l}\text { Michael J. Artis } \\
\text { (comment by David } \\
\text { Archer) }\end{array}$ & 69 & $\begin{array}{l}\text { Reflections on the Optimal Currency Area } \\
\text { (OCA) criteria in the light of EMU }\end{array}$ \\
\hline August 5, 2002 & $\begin{array}{l}\text { Jürgen von Hagen, } \\
\text { Susanne Mundschenk } \\
\text { (comments by Thorsten } \\
\text { Polleit, Gernot } \\
\text { Doppelhofer and } \\
\text { Roland Vaubel) }\end{array}$ & 70 & $\begin{array}{l}\text { Fiscal and Monetary Policy Coordination in } \\
\text { EMU }\end{array}$ \\
\hline August 12, 2002 & $\begin{array}{l}\text { Dimitri Boreiko } \\
\text { (comment by Ryszard } \\
\text { Kokoszczyński) }\end{array}$ & 71 & $\begin{array}{l}\text { EMU and Accession Countries: } \\
\text { Cluster Analysis of Membership }\end{array}$ \\
\hline August 19, 2002 & $\begin{array}{l}\text { Ansgar Belke and } \\
\text { Daniel Gros (comments } \\
\text { by Luís de Campos e } \\
\text { Cunha, Nuno Alves and } \\
\text { Eduardo Levy-Yeyati) }\end{array}$ & 72 & $\begin{array}{l}\text { Monetary Integration in the Southern Cone: } \\
\text { Mercosur Is Not Like the EU? }\end{array}$ \\
\hline August 26, 2002 & $\begin{array}{l}\text { Friedrich Fritzer, } \\
\text { Gabriel Moser and } \\
\text { Johann Scharler }\end{array}$ & 73 & $\begin{array}{l}\text { Forecasting Austrian HICP and its } \\
\text { Components using VAR and ARIMA Models }\end{array}$ \\
\hline
\end{tabular}




\begin{tabular}{|c|c|c|c|}
\hline $\begin{array}{l}\text { September 30, } \\
2002\end{array}$ & Sebastian Edwards & 74 & $\begin{array}{l}\text { The Great Exchange Rate Debate after } \\
\text { Argentina }\end{array}$ \\
\hline $\begin{array}{l}\text { October 3, } \\
2002\end{array}$ & $\begin{array}{l}\text { George Kopits } \\
\text { (comments by Zsolt } \\
\text { Darvas and Gerhard } \\
\text { Illing) }\end{array}$ & 75 & $\begin{array}{l}\text { Central European EU Accession and } \\
\text { Latin American Integration: Mutual Lessons } \\
\text { in Macroeconomic Policy Design }\end{array}$ \\
\hline $\begin{array}{l}\text { October 10, } \\
2002\end{array}$ & $\begin{array}{l}\text { Eduard Hochreiter, } \\
\text { Anton Korinek and } \\
\text { Pierre L. Siklos } \\
\text { (comments by Jeannine } \\
\text { Bailliu and Thorvaldur } \\
\text { Gylfason) }\end{array}$ & 76 & $\begin{array}{l}\text { The Potential Consequences of Alternative } \\
\text { Exchange Rate Regimes: } \\
\text { A Study of Three Candidate Regions }\end{array}$ \\
\hline October 14, 2002 & $\begin{array}{l}\text { Peter Brandner, Harald } \\
\text { Grech }\end{array}$ & 77 & $\begin{array}{l}\text { Why Did Central Banks Intervene in the } \\
\text { EMS? The Post } 1993 \text { Experience }\end{array}$ \\
\hline October 21,2002 & $\begin{array}{l}\text { Alfred Stiglbauer, } \\
\text { Florian Stahl, Rudolf } \\
\text { Winter-Ebmer, Josef } \\
\text { Zweimüller }\end{array}$ & 78 & $\begin{array}{l}\text { Job Creation and Job Destruction in a } \\
\text { Regulated Labor Market: The Case of } \\
\text { Austria }\end{array}$ \\
\hline October 28, 2002 & $\begin{array}{l}\text { Elsinger, Alfred Lehar } \\
\text { and Martin Summer }\end{array}$ & 79 & Risk Assessment for Banking Systems \\
\hline $\begin{array}{l}\text { November 4, } \\
2002\end{array}$ & Helmut Stix & 80 & $\begin{array}{l}\text { Does Central Bank Intervention Influence } \\
\text { the Probability of a Speculative Attack? } \\
\text { Evidence from the EMS }\end{array}$ \\
\hline June 30, 2003 & $\begin{array}{l}\text { Markus Knell, Helmut } \\
\text { Stix }\end{array}$ & 81 & $\begin{array}{l}\text { How Robust are Money Demand } \\
\text { Estimations? A Meta-Analytic Approach }\end{array}$ \\
\hline July 7,2003 & Helmut Stix & 82 & $\begin{array}{l}\text { How Do Debit Cards Affect Cash Demand? } \\
\text { Survey Data Evidence }\end{array}$ \\
\hline July 14,2003 & Sylvia Kaufmann & 83 & $\begin{array}{l}\text { The business cycle of European countries. } \\
\text { Bayesian clustering of country-individual IP } \\
\text { growth series. }\end{array}$ \\
\hline July 21,2003 & $\begin{array}{l}\text { Jesus Crespo } \\
\text { Cuaresma, Ernest } \\
\text { Gnan, Doris Ritzberger- } \\
\text { Gruenwald }\end{array}$ & 84 & $\begin{array}{l}\text { Searching for the Natural Rate of Interest: a } \\
\text { Euro-Area Perspective }\end{array}$ \\
\hline July 28, 2003 & $\begin{array}{l}\text { Sylvia Frühwirth- } \\
\text { Schnatter, Sylvia } \\
\text { Kaufmann }\end{array}$ & 85 & $\begin{array}{l}\text { Investigating asymmetries in the bank } \\
\text { lending channel. An analysis using Austrian } \\
\text { banks' balance sheet data }\end{array}$ \\
\hline
\end{tabular}




\begin{tabular}{|c|c|c|c|}
\hline $\begin{array}{l}\text { September 22, } \\
2003\end{array}$ & Burkhard Raunig & 86 & $\begin{array}{l}\text { Testing for Longer Horizon Predictability of } \\
\text { Return Volatility with an Application to the } \\
\text { German DAX }\end{array}$ \\
\hline May 3, 2004 & $\begin{array}{l}\text { Juergen Eichberger, } \\
\text { Martin Summer }\end{array}$ & 87 & Bank Capital, Liquidity and Systemic Risk \\
\hline June 7,2004 & $\begin{array}{l}\text { Markus Knell, Helmut } \\
\text { Stix }\end{array}$ & 88 & $\begin{array}{l}\text { Three Decades of Money Demand Studies. } \\
\text { Some Differences and Remarkable } \\
\text { Similarities }\end{array}$ \\
\hline August 27, 2004 & $\begin{array}{l}\text { Martin Schneider, } \\
\text { Martin Spitzer }\end{array}$ & 89 & $\begin{array}{l}\text { Forecasting Austrian GDP using the } \\
\text { generalized dynamic factor model }\end{array}$ \\
\hline $\begin{array}{l}\text { September 20, } \\
2004\end{array}$ & $\begin{array}{l}\text { Sylvia Kaufmann, Maria } \\
\text { Teresa Valderrama }\end{array}$ & 90 & Modeling Credit Aggregates \\
\hline Oktober 4, 2004 & $\begin{array}{l}\text { Gabriel Moser, Fabio } \\
\text { Rumler, Johann } \\
\text { Scharler }\end{array}$ & 91 & Forecasting Austrian Inflation \\
\hline $\begin{array}{l}\text { November 3, } \\
2004\end{array}$ & $\begin{array}{l}\text { Michael D. Bordo, Josef } \\
\text { Christl, Harold James, } \\
\text { Christian Just }\end{array}$ & 92 & $\begin{array}{l}\text { Exchange Rate Regimes Past, Present and } \\
\text { Future }\end{array}$ \\
\hline $\begin{array}{l}\text { December 29, } \\
2004\end{array}$ & Johann Scharler & 93 & $\begin{array}{l}\text { Understanding the Stock Market's Response } \\
\text { to Monetary Policy Shocks }\end{array}$ \\
\hline $\begin{array}{l}\text { Decembert 31, } \\
2004\end{array}$ & Harald Grech & 94 & $\begin{array}{l}\text { What Do German Short-Term Interest Rates } \\
\text { Tell Us About Future Inflation? }\end{array}$ \\
\hline $\begin{array}{l}\text { February } 7 \\
2005\end{array}$ & Markus Knell & 95 & $\begin{array}{l}\text { On the Design of Sustainable and Fair } \\
\text { PAYG - Pension Systems When Cohort } \\
\text { Sizes Change. }\end{array}$ \\
\hline March 4, 2005 & $\begin{array}{l}\text { Stefania P. S. Rossi, } \\
\text { Markus Schwaiger, } \\
\text { Gerhard Winkler }\end{array}$ & 96 & $\begin{array}{l}\text { Managerial Behavior and Cost/Profit } \\
\text { Efficiency in the Banking Sectors of Central } \\
\text { and Eastern European Countries }\end{array}$ \\
\hline April 4, 2005 & Ester Faia & 97 & $\begin{array}{l}\text { Financial Differences and Business Cycle } \\
\text { Co-Movements in A Currency Area }\end{array}$ \\
\hline May 12,2005 & Federico Ravenna & 98 & $\begin{array}{l}\text { The European Monetary Union as a } \\
\text { Committment Device for New EU Member } \\
\text { States }\end{array}$ \\
\hline
\end{tabular}




\begin{tabular}{|c|c|c|c|}
\hline May 23,2005 & $\begin{array}{l}\text { Philipp Engler, Terhi } \\
\text { Jokipii, Christian Merkl, } \\
\text { Pablo Rovira Kalt- } \\
\text { wasser, Lúcio Vinhas } \\
\text { de Souza }\end{array}$ & 99 & $\begin{array}{l}\text { The Effect of Capital Requirement } \\
\text { Regulation on the Transmission of Monetary } \\
\text { Policy: Evidence from Austria }\end{array}$ \\
\hline July 11,2005 & $\begin{array}{l}\text { Claudia Kwapil, Josef } \\
\text { Baumgartner, Johann } \\
\text { Scharler }\end{array}$ & 100 & $\begin{array}{l}\text { The Price-Setting Behavior of Austrian } \\
\text { Firms: Some Survey Evidence }\end{array}$ \\
\hline July 25, 2005 & $\begin{array}{l}\text { Josef Baumgartner, } \\
\text { Ernst Glatzer, Fabio } \\
\text { Rumler, Alfred } \\
\text { Stiglbauer }\end{array}$ & 101 & $\begin{array}{l}\text { How Frequently Do Consumer Prices } \\
\text { Change in Austria? } \\
\text { Evidence from Micro CPI Data }\end{array}$ \\
\hline August 8, 2005 & Fabio Rumler & 102 & $\begin{array}{l}\text { Estimates of the Open Economy New } \\
\text { Keynesian Phillips Curve for Euro Area } \\
\text { Countries }\end{array}$ \\
\hline $\begin{array}{l}\text { September 19, } \\
2005\end{array}$ & $\begin{array}{l}\text { Peter Kugler, Sylvia } \\
\text { Kaufmann }\end{array}$ & 103 & $\begin{array}{l}\text { Does Money Matter for Inflation in the Euro } \\
\text { Area? }\end{array}$ \\
\hline
\end{tabular}

